

\title{
COMPORTAMENTO DO SISTEMA RADICULAR DO CAPIM TANZÂNIA (Panicum maximum, Jacq.) SOB IRRIGAÇÃO E SUBMETIDO A DIFERENTES INTENSIDADES DE PASTEJO
}

\author{
DANIEL SILVA PAGOTTO \\ Engenheiro Agrônomo
}

Orientador: Prof. Dr. Moacyr Corsi

\begin{abstract}
Dissertação apresentada à Escola Superior de Agricultura "Luiz de Queiroz, Universidade de São Paulo, para obtenção do título de Mestre em Agronomia, Área de Concentração: Ciência Animal e Pastagens
\end{abstract}

\author{
PIRACICABA \\ Estado de São Paulo - Brasil \\ Dezembro - 2001
}


Dados Internacionais de Catalogação na Publicação (CIP)
DIVISÃO DE BIBLIOTECA E DOCUMENTAÇÃO - ESALO/USP

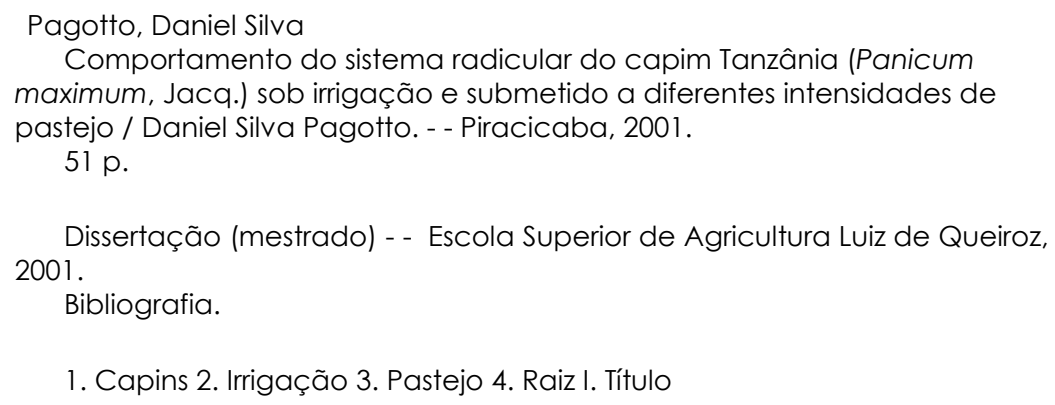

CDD 633.2

\section{"Permitida a cópia total ou parcial deste documento, desde que citada a fonte - $\mathrm{O}$ autor"}




\title{
Aos meus pais Sidnei e Maria Dalva,
}

pelo apoio, incentivo e dedicação durante esta jornada

\author{
À minha irmã Mariana, \\ pelo amor e amizade
}

Dedico 


\section{AGRADECIMENTOS}

O meu grande agradecimento ao Prof. Dr. Moacyr Corsi, pela fundamental contribuição à minha formação e pela oportunidade em desenvolver este estudo.

À Fundação de Amparo à Pesquisa do Estado de São Paulo FAPESP, pela concessão da bolsa de estudos e financiamento do projeto de pesquisa e também pela eficiência e seriedade na utilização dos recursos públicos a ela confiados.

Aos professores do Curso de Pós-graduação em Ciência Animal e Pastagens, pelos esclarecimentos, orientações e conhecimento transmitido.

À equipe de pós-graduandos do Projeto CAPIM: Geraldo B. Martha Júnior, Patrícia Menezes Santos, Marco Antônio Penati, Marco Antônio Balsalobre e Luis Gustavo Barioni, pela experiência e troca de conhecimentos.

A todos os estagiários do Projeto CAPIM, pelo auxilio nas coletas e processamento de amostras, e sem os quais este estudo teria sua viabilidade dificultada.

Ao Prof. Dr. Ricardo Ferraz de Oliveira pelas idéias na elaboração do projeto e por possibilitar a utilização do "Laboratório de Plantas Cultivadas sob Condições de Estresse".

Aos meus amigos de São José do Rio Preto, pelo incentivo e companheirismo.

Aos amigos da República Senzala, pelo companheirismo e histórias que ficarão para sempre. 
À Escola Superior de Agricultura "Luiz de Queiroz" pela minha formação profissional.

Aos colegas do Curso de Pós-graduação em Ciência Animal e Pastagens, e em especial para o Geraldo Bueno Martha Júnior e para o Hugo Imaizumi pelo apoio na finalização do trabalho.

OBRIGADO 


\section{SUMÁRIO}

página



ISTA DE TABELAS ……....................................................................... ix

RESUMO ….............................................................................. Xi

SUMMARY..........................................................................................

IINTRODUÇÃO .........................................................................................1

2REVISÃO DE LITERATURA ...................................................................

2.1 Aspectos ecofisiológicos relacionados à desfolha .....................................

2.2 A interação sistema radicular - parte aérea.................................................

2.3 A interação sistema radicular - solo ......................................................10

3 MATERIAL E MÉTODOS ........................................................................13

8.1 Local...............................................................................................13

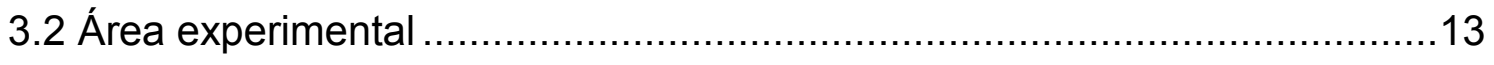

3.3 Amostragens e parâmetros a serem determinados: …………...................14

3.3.1 Experimento 1 ................................................................................. 14

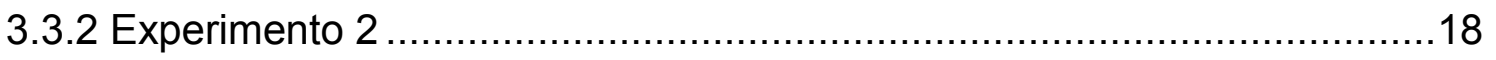

3.4 Análise estatística ……………………………………………………..19

y RESULTADOS E DISCUSSÃ 
4.1 EXPERIMENTO I - Dinâmica do sistema radicular do capim Tanzânia

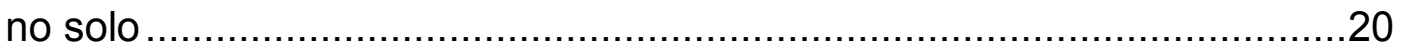

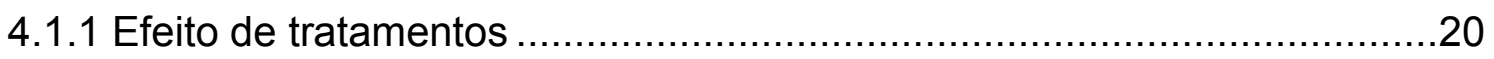

4.4.1 Efeitos de épocas no mesmo ciclo de pastejo ...................................

4.2 EXPERIMENTO II - Dinâmica da retomada de crescimento do sistema radicular do capim Tanzânia após o pastejo..............................35

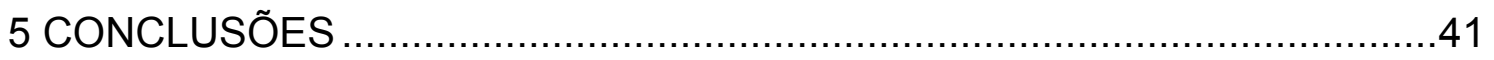

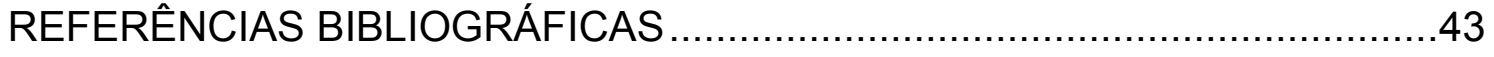




\section{LISTA DE FIGURAS}

página

1 Trado/sonda utilizado para coleta de amostras .

2 Scanner de mesa acoplado ao Software Modelo DELTA - T para

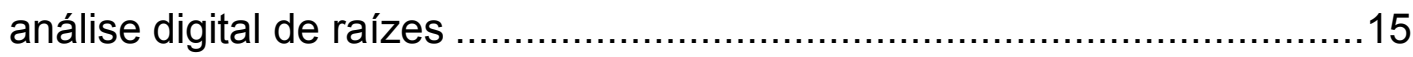

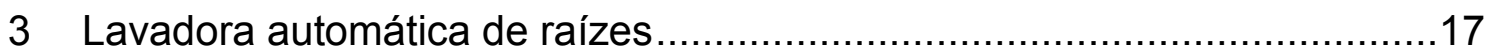

$4 \quad$ Esquema de funcionamento da lavadora de raízes .........................17

5 Porcentagem de raízes vivas e mortas do capim Tanzânia irrigado para diferentes resíduos pós pastejo (T1 - 1000 kg MSV.ha-1; T2 2500 kg MSV.ha-1; T3 - 4000 kg MSV.ha ${ }^{-1}$ ) entre novembro de 1999 e

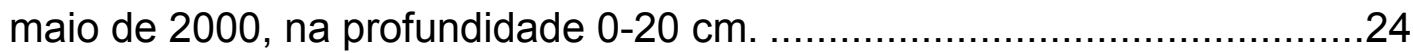

6 Porcentagem de raízes vivas e mortas do capim Tanzânia irrigado para diferentes resíduos pós pastejo (T1 - 1000 kg MSV.ha-1; T2 2500 kg MSV.ha ${ }^{-1}$; T3 - 4000 kg MSV.ha ${ }^{-1}$ ) entre novembro de 1999 e

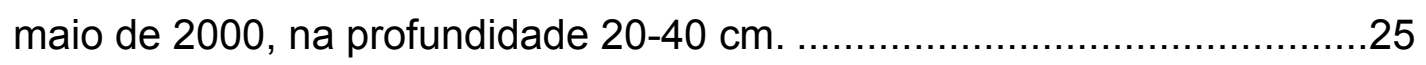

7 Crescimento pós-desfolha do sistema radicular do capim Tanzânia irrigado submetido a três resíduos pós-pastejo no período de primavera, para a profundidade $0-20 \mathrm{~cm}$.

8 Crescimento pós-desfolha do sistema radicular do capim Tanzânia irrigado submetido a três resíduos pós-pastejo no período de verão, para a profundidade $0-20 \mathrm{~cm}$ 


\section{LISTA DE TABELAS}

página

1 Desenvolvimento radicular do capim Tanzânia irrigado para diferentes

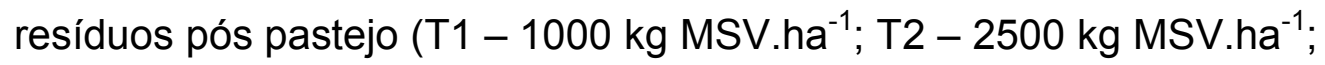

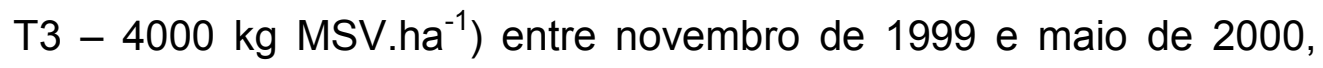

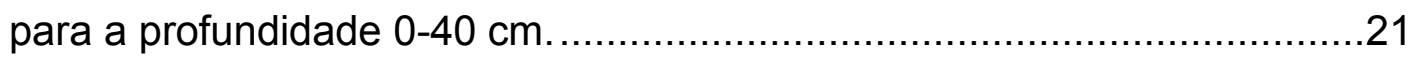

2 Massa de raízes vivas do capim Tanzânia irrigado para diferentes

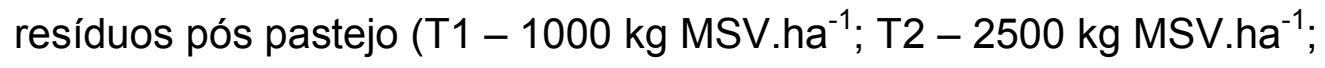
T3 - 4000 kg MSV.ha ${ }^{-1}$ ) entre novembro de 1999 e maio de 2000, na

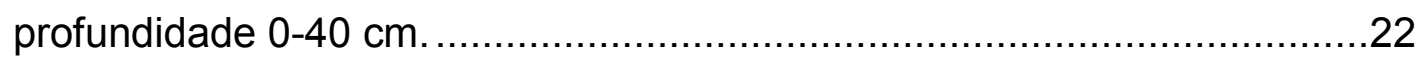

3 Massa de raízes vivas do capim Tanzânia irrigado para diferentes

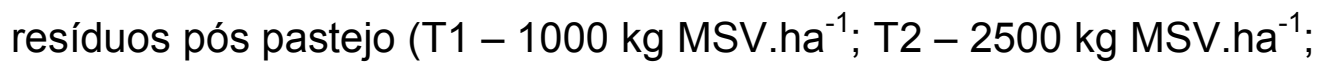

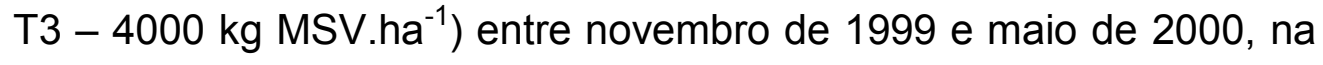

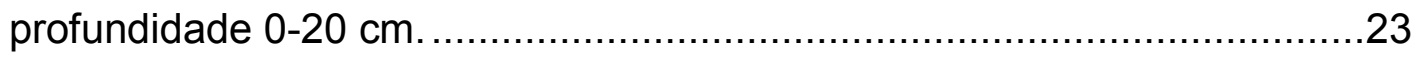

4 Massa de raízes vivas do capim Tanzânia irrigado para diferentes

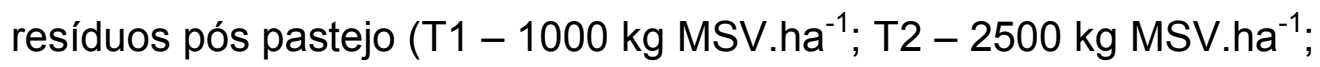
T3 - 4000 kg MSV.ha ${ }^{-1}$ ) entre novembro de 1999 e maio de 2000, na

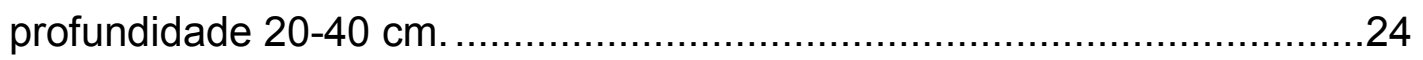

5 Desenvolvimento radicular do capim Tanzânia irrigado para diferentes

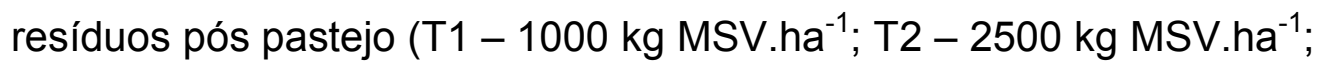

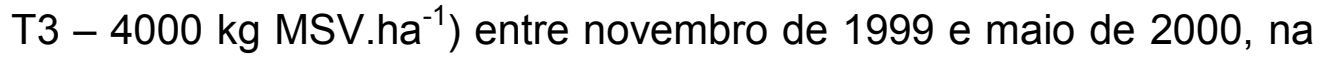
profundidade $0-20 \mathrm{~cm}$. 
6 Massa de raízes mortas do capim Tanzânia irrigado para diferentes

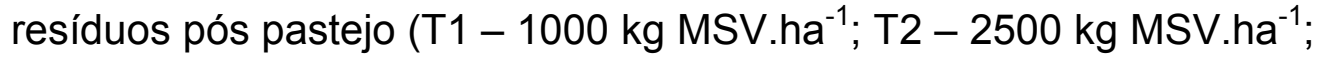
T3 - 4000 kg MSV.ha ${ }^{-1}$ ) entre novembro de 1999 e maio de 2000, nas

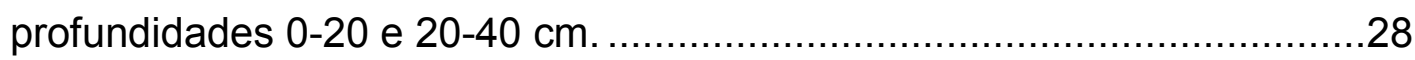

7 Desenvolvimento do sistema radicular de capim Tanzânia irrigado para 5 diferentes épocas em três ciclos de pastejo, entre novembro

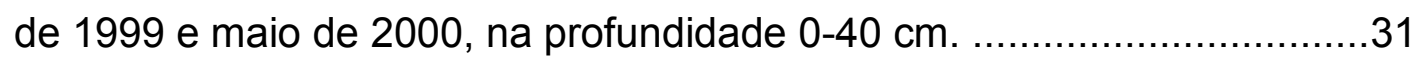

8 Massa de raízes vivas do capim Tanzânia irrigado para 5 diferentes épocas em três ciclos de pastejo, entre novembro de 1999 e maio de

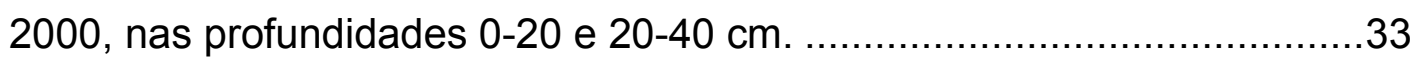

9 Massa de raízes mortas do capim Tanzânia irrigado para 5 diferentes épocas em três ciclos de pastejo, entre novembro de 1999 e maio de 2000 , nas profundidades $0-20$ e $20-40 \mathrm{~cm}$.

10 Desenvolvimento em areia do sistema radicular do capim Tanzânia

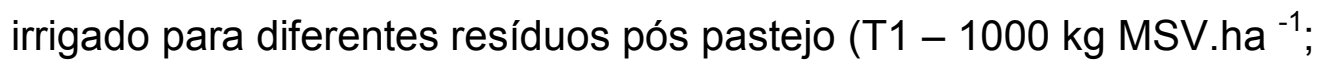
T2 - $2500 \mathrm{~kg} \mathrm{MSV} \cdot \mathrm{ha}^{-1}$; T3 - $4000 \mathrm{~kg} \mathrm{MSV} \cdot \mathrm{ha}^{-1}$ ), na profundidade 0-

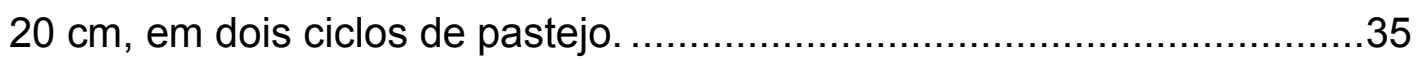

11 Desenvolvimento em areia do sistema radicular de capim Tanzânia irrigado para diferentes épocas em dois ciclos de pastejo, na profundidade $0-20 \mathrm{~cm}$ 


\title{
COMPORTAMENTO DO SISTEMA RADICULAR DO CAPIM TANZÂNIA (Panicum maximum, Jacq.) SOB IRRIGAÇÃO E SUBMETIDO A DIFERENTES INTENSIDADES DE PASTEJO
}

\author{
Autor: DANIEL SILVA PAGOTTO \\ Orientador: Prof. Dr. MOACYR CORSI
}

\section{RESUMO}

O presente estudo foi realizado na Fazenda Areão, unidade da Escola Superior de Agricultura "Luiz de Queiroz", em Piracicaba - SP (22 $42^{\prime} 30^{\prime \prime}$ Latitude Sul ; 47³8'30" Longitude Oeste) e teve por objetivo avaliar a dinâmica do sistema radicular do capim Tanzânia (Panicum maximum, Jacq.) quando submetido a três intensidades de manejo, correspondidas pelos resíduos pós pastejo de 1000, 2500 e $4000 \mathrm{~kg}$ de matéria seca verde por hectare (MSV.ha-1). A área experimental foi irrigada por pivô central, sendo pastejada por novilhos da raça nelore e manejada de forma rotacionada com ciclo de 36 dias, sendo 3 dias de ocupação e 33 dias de descanso. Foram realizadas análises quantitativas da densidade radicular através de sua massa, superfície e comprimento. As análises qualitativas se relacionaram à separação entre as raízes vivas e mortas, de maneira que pudéssemos verificar mais efetivamente o real potencial de absorção para os diferentes tratamentos, assim como o 
estresse imposto pelo pastejo em cada situação. O desenvolvimento do sistema radicular do capim Tanzânia mostrou comportamento inversamente proporcional às intensidades de pastejo impostas, relacionando pastejos intensos a uma retomada mais lenta na atividade de raízes. Nas condições de

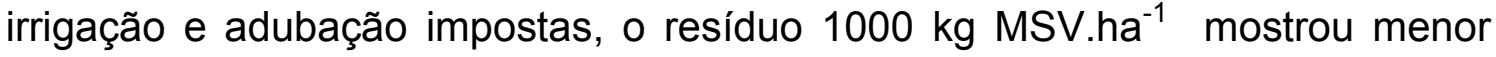
atividade radicular em relação aos tratamentos de 2500 e $4000 \mathrm{~kg} \mathrm{MSV}$.ha ${ }^{-1}$ de resíduo pós pastejo. Até 12 dias após o pastejo não houve crescimento de novas raízes, indicando que a planta fica sob condição de estresse até pelo menos 2 semanas após ser colhida, independente do manejo imposto. No

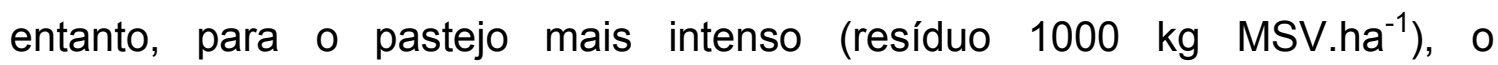
desenvolvimento radicular ficou comprometido até 21 dias após o pastejo. Para as profundidades analisadas $(0-20$ e 0-40 cm), na média dos 3 tratamentos, em torno de $76 \%$ das raízes vivas e $82 \%$ das raízes mortas foram encontradas nos primeiros $20 \mathrm{~cm}$ de solo. Estes resultados indicam a possibilidade de novas pesquisas utilizarem apenas esta profundidade para amostragens, uma vez que os valores são relevantes e a dificuldade de coleta em maiores profundidades é fator limitante para trabalhos com raízes. A separação de raízes vivas pareceu ser uma boa metodologia para melhorar a acuracidade na análise dos resultados, já que amostragens do sistema radicular de plantas forrageiras apresentam variabilidade alta. Estudos que relacionem a decomposição e renovação do sistema radicular de forrageiras tropicais com fatores bióticos e abióticos deveriam ser intensificados, buscando melhor entendimento dos fluxos de tecidos da planta inteira em diferentes estações do ano. Metodologias de amostragens associadas a conceitos de interpretação estatística em processos biológicos deveriam ser revistos, uma vez que os estudos existentes sobre sistema radicular de plantas forrageiras tropicais poucas vezes são conclusivos quando interpretados pela estatística ortodoxa. 


\title{
ROOT SYSTEM DYNAMICS OF IRRIGATED TANZANIA GRASS (Panicum maximum) PASTURE MANAGED UNDER DIFFERENT GRAZING INTENSITIES
}

\author{
Author: DANIEL SILVA PAGOTTO \\ Adviser: Prof. Dr. MOACYR CORSI
}

\section{SUMMARY}

The present study was carried out at Escola Superior de Agricultura

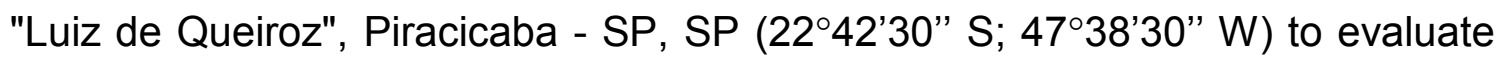
the root system dynamics of irrigated Tanzania grass (Panicum maximum cv. Tanzania) pasture managed under three grazing intensities, determinated by adjusting the post grazing residues to 1000,2500 and $4000 \mathrm{~kg}$ of green dry matter per hectare $\left(\mathrm{GDM} . \mathrm{ha}^{-1}\right)$. The experimental area was irrigated by a central pivot system. Nelore steers were used in a 36 days rotational grazing system, represented by an occupation period of 3 days and resting period of 33 days. Quantitative and qualitative evaluations were both performed. In the former case the variables measured were root mass, surface and length. In the latter case, collected samples were separated into live and dead roots, providing a reliable way to assess grazing intensity effects upon root system dynamics. Root system development responded inversely to grazing intensity. Hard grazing (1000 kg GDM.ha $^{-1}$ ) was associated to slower root system regrowth compared to 
moderate (2500 kg GDM.ha- $\left.{ }^{-1}\right)$ and lenient (4000 kg GDM.ha-1) grazing. In the $1000 \mathrm{~kg} \mathrm{GDM} . \mathrm{ha}^{-1}$ post-grazing residue no root development was observed up to three weeks, whereas for the other two treatments root regrowth was reactivated after 12 days. The three treatments averaged, $76 \%$ and $82 \%$ of live and dead roots, respectively, were found in the $0-20 \mathrm{~cm}$ soil layer. This information might suggest further research on root system dynamics could focus on sampling in the range of $0-20 \mathrm{~cm}$ depth. This seems reasonable, since the results obtained in this soil layer were representative and also because root samplings in depth greater than $20 \mathrm{~cm}$ (e.g. 20-40 cm) are not so easy to be performed as compared to samplings taken from $0-20 \mathrm{~cm}$. Sample separation into live and dead roots provided a reliable and more accurate method to analyze the data. In part, this can be attributed to lower variability among samples. It is important to stress that additional work has to be undertaken to study decomposition and turnover of the root system of tropical pastures, as well as the relationship between these variables with biotic and abiotic factors. This effort should provide a better understanding on tissue turnover of the plant as a whole (shoots and root system). Finally, improved methods on root samplings should be developed. Also, new concepts on statistical interpretation for biological processes should be emphasized, due to difficulties in interpreting data on root system by conventional statistical methods. 


\section{INTRODUÇÃO}

A maior parte das pesquisas com plantas forrageiras se concentra em estudos apenas de sua parte aérea. Há mais de duas décadas Davidson (1978) mencionava ser surpreendente a existência de tão poucos dados relacionados a pesquisas sobre raízes, mencionando-as como o "componente esquecido" das pastagens.

A atual situação da pesquisa centrada em estudos de sistemas radiculares parece continuar caminhando a passos lentos, principalmente no caso de forrageiras tropicais. Dada situação é ratificada por Bono et al. (2000), enfatizando a falta de informações disponíveis sobre a produção de biomassa e morfologia do sistema radicular de forrageiras e por Scurlock \& Hall (1998), estimando em menos de $10 \%$ os estudos mundiais sobre pastagens com medições diretas da biomassa subterrânea.

A quantificação de raízes é um dos processos mais dispendiosos, em termos de recursos humanos e financeiros, na avaliação de impactos ambientais em diferentes ecossistemas (Amaral, 1998). No entanto, é um parâmetro eficaz para avaliação dos efeitos do uso da terra, principalmente no que diz respeito à sua relação com o sistema solo-planta.

Sabe-se da existência de um sistema integrado de funcionamento entre raízes e parte aérea nas plantas. Esta interação, associada a fatores ligados ao manejo, solo e clima é que serão responsáveis pela produção e perenidade da pastagem.

Desta maneira mostra-se fundamental um melhor entendimento da dinâmica do sistema radicular de plantas forrageiras sob diferentes intensidades 
de pastejo. Assim, uma busca por informações relacionadas a raízes, que permita inferir sobre o estado fisiológico da planta e seu potencial de recuperação após o pastejo ou corte, poderá auxiliar sensivelmente em práticas de manejo destas forrageiras.

Dadas as ótimas condições do Brasil à exploração de bovinos sob pastagens e a relevância que vem tomando a intensificação de sistemas de produção animal a pasto nos últimos anos, cresce a necessidade de pesquisas que considerem a interface solo-planta para melhor entendimento da reação da planta forrageira sob pastejo.

O presente estudo teve o objetivo de gerar dados relacionados ao sistema radicular de uma forrageira tropical, que possibilitem fornecer subsídios para recomendações mais confiáveis no manejo de pastagens de alta produtividade, mais especificamente em sistemas irrigados. 


\section{REVISÃO DE LITERATURA}

\subsection{Aspectos ecofisiológicos relacionados à desfolha}

Gomide (1997) em referência a sistemas de pastejo rotacionado, mencionou que a vegetação sofre uma grande variação no seu índice de área foliar (IAF) desde o valor máximo, existente no início do pastejo, até um valor mínimo ao término deste. Sob tais condições, a recuperação da forragem acontece segundo uma curva sigmoidal de crescimento (Corsi, 1994; Gomide, 1997), caracterizada por três fases: (I) ocorre quando do início da fase de rebrota, sendo caracterizado por IAF mínimo e reduzidos acréscimos diários de produção; (II) observado através de rápido ritmo de crescimento da forragem, refletindo grande aumento de área foliar de alta eficiência fotossintética e

proporcionando crescimento vigoroso e linear; (III) representado por taxas de crescimento decrescentes tendendo para a estabilização e posterior decréscimo da produção líquida de forragem.

Nesse contexto, a pronta recuperação da planta forrageira após a desfolha pode ser influenciada pela porcentagem de preservação de pontos de crescimento nos quais a rebrota poderá ocorrer, pelos teores de reservas metabólicas nitrogenadas e de carboidratos e pela área foliar remanescente (Milthorpe \& Davidson, 1966; Youngner, 1972; Harris, 1978; Rodrigues \& Rodrigues, 1987; Humphreys, 1966, 1991; Nabinger, 1997).

A preservação do meristema apical como fator de resposta de forrageiras à rápida recuperação após a desfolha parece ter potencial limitado para plantas cespitosas em sistemas de alta produtividade (Corsi, 1994), pois 
além das condições edafoclimáticas favoráveis ao crescimento, a adubação nitrogenada, que é fundamental para o incremento da produtividade através do aumento da área foliar, provoca a elongação precoce das hastes (Corsi 1984), impossibilitando a preservação do meristema apical no pastejo. Nestes casos deve-se partir para técnicas que busquem um aumento no perfilhamento, em número e/ou peso de perfilhos (Corsi, 1994).

Outro fator de influência na rebrota de plantas forrageiras trata-se do teor de carboidratos não estruturais armazenados no tecido residual. Porém, quando se menciona a importância destas reservas orgânicas para o vigor de rebrota após corte ou pastejo, entramos na discussão de um dos tópicos mais controversos da agronomia de pastagens (Silva \& Pedreira, 1997).

Estes carboidratos não estruturais de reserva, que são acumulados principalmente na base das hastes e raízes das plantas (Harris, 1978; Donaghy \& Fulkerson, 1998), tem sua concentração reduzida por ocasião da desfolha, sendo essa redução diretamente proporcional à severidade e frequência de desfolha (Youngner, 1972; Smith, 1973; Adjei, 1988; Donaghy \& Fulkerson, 1998). O nível destes carboidratos nas plantas forrageiras também varia nos diferentes órgãos da planta conforme seu estágio fisiológico, estado nutricional e condições de ambiente (Smith, 1973), além da variação sazonal (Soares Filho, 1991).

Smith (1973) relatou que os carboidratos não estruturais representam uma fonte prontamente metabolizável de energia para o crescimento e a sobrevivência da planta. Estudos com espécies forrageiras tropicais (Botrel, 1980; Nascimento et al., 1980; Gross, 1988) ou temperadas (Adjei et al. 1988; Donaghy \& Fulkerson, 1998) confirmaram a correlação entre níveis de carboidratos não estruturais e vigor de rebrota. Entretanto, outros resultados indicam que a produção de matéria seca da rebrota não depende do teor de carboidratos na ocasião da desfolha (Gomide et al., 1979; Jones \& Carabaly, 1981). Humphreys (1991) em argumentação sobre o tema relatou que a translocação de carboidratos de reserva das raízes e colo da planta em direção 
aos meristemas influencia o crescimento apenas de maneira transitória e pouco significativa.

$\mathrm{Na}$ verdade, evidências destes trabalhos indicam que a rebrota da planta forrageira é dependente dos carboidratos de reserva até que a área foliar formada seja suficiente para atender as necessidades do perfilho, isto é, o perfilho em rebrota passa do estágio de dreno para fonte metabólica.

O terceiro fator de resposta das plantas forrageiras à desfolha tratase da área foliar remanescente, e começou a ser difundido por Brougham (1956) com estudos sobre velocidade de rebrota em azevém. Este autor submeteu as plantas a diferentes intensidades de desfolha e constatou que plantas com altura de corte mais elevada, portanto com maior área foliar remanescente, levaram menor período de tempo para atingir o IAF crítico (IAF no qual as folhas interceptam $95 \%$ da luz incidente) do que plantas desfolhadas com maior intensidade. Em colocação mais abrangente, Humphreys (1991) mencionou que a taxa de reposição da superfície foliar após a desfolha depende da extensão da área foliar residual e sua capacidade fotossintética, da densidade de folhas que permanecem capazes de expandir, da densidade de gemas presentes e sua expansão e diferenciação posterior, além dos fatores ambientais.

Corsi (1994), fazendo referência ao manejo de pastagens de alta produtividade, ressaltou a necessidade de intensificação da produção de folhas novas, a fim de se obter rápido aumento na área fotossintética após o corte. Em estudos com Panicum maximum, Chacón-Moreno et al. (1995) ratificam a idéia, verificando que para uma dada quantidade de luz, a taxa fotossintética foi maior nas folhas verdes recém expandidas, seguida pelas folhas novas em expansão e estas seguidas pelas folhas de avançada idade fisiológica.

Em contrapartida, Harris (1978) inferiu que o aumento na severidade dos cortes poderia afetar negativamente o consumo de nutrientes pelas plantas forrageiras diminuindo a taxa de reposição de folhas, em função de: (I) redução do sistema radicular em decorrência à desfolha, podendo limitar a exploração 
de água e nutrientes do solo; (II) a desfolha diminuir a transpiração e restringir a absorção de nutrientes; (III) a desfolha restringir o fluxo de fotossintetizados e consequentemente os substratos para a respiração das raízes limitando a absorção ativa de nutrientes.

Deste modo, à medida que a parte aérea de plantas forrageiras é utilizada por corte ou pastejo há decréscimo na fotossíntese prejudicando o desenvolvimento de novos perfilhos e novas raízes no sentido de beneficiar a recuperação da área foliar remanescente após a desfolha (Donaghy \& Fulkerson, 1998; Corsi et al., 2001).

Rodrigues \& Rodrigues (1987) também relacionaram desfolhas intensas a um período inicial de rebrota mais longo, o que pode diminuir o número de ciclos de utilização da pastagem durante a estação de crescimento e, possivelmente, reduzir a produção a cada ciclo de rebrota.

Estudos mais recentes (Lemaire \& Chapman, 1996; Lemaire, 1997; Martha Júnior, 1999; Louahlia et al., 2000) tem dado suporte à idéia de que a reserva nitrogenada da planta forrageira também seria um fator fundamental à pronta recuperação da planta após o corte ou pastejo.

Segundo Lemaire \& Chapman (1996), até $80 \%$ do nitrogênio presente na parte aérea formada na primeira semana após o corte, pode ser proveniente da translocação a partir de raízes e hastes, sendo o restante proveniente da absorção via solo. Entretanto, o padrão de remobilização destas reservas nitrogenadas até o novo tecido está associado à quantidade de nitrogênio presente no sistema solo - planta (Corsi et al., 2001). Millard et al. (1990) mostraram que $50 \%$ do nitrogênio transferido para a nova lâmina foliar a partir das raízes e do resíduo pós-pastejo ocorreu após 4,5 dias quando a disponibilidade de nitrogênio era alta porém, para situação de baixa disponibilidade do elemento o período necessário para a mesma translocação foi de 11 dias.

Com isso, entendemos que, associado a estudos que relacionem tecido meristemático, carboidratos de reserva e área foliar residual, deveria se 
dar ênfase a trabalhos que relacionem as reservas nitrogenadas na planta e níveis de nitrogênio no solo como fator de influência na recuperação de plantas forrageiras após a desfolha por corte ou pastejo.

\subsection{A interação sistema radicular - parte aérea}

A velocidade de recuperação das pastagens parece, portanto, depender da reposição da área foliar (Rodrigues \& Rodrigues, 1987), que está associada ao perfilhamento, expansão das folhas, área foliar remanescente e carboidratos de reserva (Milthorpe \& Davidson, 1966; Humphreys, 1991) e reservas nitrogenadas (Lemaire \& Chapman 1996).

O perfilhamento e expansão da área foliar estão correlacionados a fatores edafoclimáticos como temperatura, radiação fotossinteticamente ativa, umidade e fertilidade do solo (Jewiss, 1972; Brouwer, 1983). A absorção de água e de nutrientes é, entretanto, dependente do crescimento contínuo do sistema radicular, uma vez que a principal área de absorção corresponde às regiões recém formadas ou mais jovens das raízes (Mengel \& Kirkby, 1982; Hopkins, 1995).

Desse modo, é provável que a redução do vigor de rebrota logo após a desfolha deva-se, além da velocidade de recuperação da área foliar, da intensidade de crescimento do sistema radicular.

Davidson (1978) reportou que pouco se conhecia sobre raízes em sistemas de pastejo e que este componente era raramente considerado em decisões de manejo. Sabe-se, no entanto, que a paralisação do crescimento e a mortalidade do sistema radicular após a desfolha ocorrem em dependência da intensidade do pastejo (Humphreys, 1991; Matthew, 1992).

Dovrat et al. (1980), observaram em Chloris gayana uma redução na matéria seca de raízes proporcional à intensidade de desfolha, sendo os efeitos mais significativos sobre o sistema radicular durante a primeira semana após o corte ou pastejo. Estes autores completam sua abordagem apontando que, 
após o período inicial de estresse após a desfolha, ocorre um incremento na massa radicular, que é relativamente constante e proporcional ao crescimento da parte aérea.

Estudos de Donaghy \& Fulkerson (1998) sobre alocação de reservas em azevém (Lollium perene) determinaram alterações na recuperação de raízes com um aumento na severidade do manejo. Nesta situação a elongação do sistema radicular, que se iniciava 4 dias após a desfolha quando o manejo para a espécie forrageira estava adequado, aumentou para 7 a 8 dias quando a planta foi mantida sob maior intensidade e/ou freqüência de desfolha.

Segundo Corsi \& Nascimento Júnior (1994), quando a produção de matéria seca diminui sensivelmente a ponto de ser notada através da lotação animal, a planta forrageira já reduziu drasticamente o sistema radicular, o perfilhamento, a expansão de folhas novas e os níveis de reservas de carboidratos nas raízes e base de hastes. Isto pode ser dimensionado através de trabalho clássico de Humphreys \& Robinson (1966), onde observaram para Panicum maximum var. Trichoglume, que uma redução de $8 \%$ na produção de matéria seca do capim reduziu 3,8 vezes o sistema radicular, 4,0 vezes o nível de carboidratos não estruturais de reserva e 1,7 vez a taxa de aparecimento de folhas novas.

Humphreys (1991) reafirmou a idéia supracitada ressaltando que desfolhas severas causam paralisação do crescimento radicular e diminuição da massa de raízes. Mencionou ainda que a redução no crescimento de raízes após a desfolha trata-se de um fenômeno universal e amplamente conhecido em plantas herbáceas.

A paralisação temporária ou redução no ritmo de crescimento do sistema radicular pode ocorrer devido à utilização de suas reservas radiculares em favor da recuperação de sua parte aérea (Taylor, 1981), além de que nesta fase a planta forrageira possui um sistema radicular muito maior do que seria necessário para suprir a parte aérea com água e nutrientes (Sheehy \& Johnson, 1988). Entretanto, Sanderson et al. (1997) abordando o assunto, informaram 
que sob severa desfolha a planta pode entrar num balanço negativo de carbono e que sua recuperação se daria através da redução imediata no crescimento radicular e reconstrução de área foliar.

Assim, a redução no crescimento radicular após a desfolha pode ser considerada como um mecanismo desejável de adaptação, o qual colabora para um restabelecimento mais rápido da área foliar e a eventual restauração do equilíbrio entre crescimento radicular e de parte aérea (Richards, 1984).

Embora existam evidências sobre a dinâmica de sistemas radiculares e sua plasticidade morfológica em sistemas agrícolas, o controle individual da senescência e decomposição de raízes finas, como no caso de gramíneas forrageiras, é pouco entendido (Vogt \& Bloomfield, 1991). Segundo estes autores, além do estresse gerado pelo manejo da desfolha, muitos fatores bióticos e abióticos estão envolvidos na senescência de raízes finas individuais, incluindo temperatura de solo, umidade, nutrientes, assim como insetos, fungos, bactérias e outros organismos de solo (Kramer \& Koslovisky, 1979; Fitter, 1999).

Fitter (1999) relatou abundância de evidências sobre a influência dos fatores ambientais sobre a longevidade do sistema radicular de plantas. Como exemplo citou estudos relacionando menor longevidade para raízes de azevém quando estas eram submetidas à temperatura de $27^{\circ} \mathrm{C}$ em relação a 15 e 21 ${ }^{\circ} \mathrm{C}$. Também relacionou vida radicular muito mais curta para plantas que receberam adubações nitrogenadas quando comparadas a outras que não foram supridas com este nutriente. Em contrapartida, Vogt \& Bloomfield (1991) não confirmaram esta idéia, apontando para o fato de que a maior parte dos modelos de simulação de crescimento assumem que raízes possuem expansão indeterminada e senescem quando condições nos microssítios de solo adjacentes a elas se tornam desfavoráveis. 


\subsection{A interação sistema radicular - solo}

A capacidade do sistema radicular em absorver água e nutrientes não aumenta em proporção ao aumento do comprimento ou da área radicular. Enquanto novas raízes com alta capacidade de absorção estão sendo produzidas, raízes mais velhas se tornam menos permeáveis (Kramer, 1983).

As modificações anatômicas que ocorrem durante a maturidade dos tecidos, por suberização, cutinização, formação de tecidos secundários, entre outros, determinarão o padrão de absorção pelas partes mais velhas da raiz (Hopkins, 1995). Fiscus \& Markhart (1979) conceituaram a real capacidade de absorção das raízes como o produto de sua superfície radicular e sua permeabilidade (condutividade hidráulica), sendo expressa como:

$$
A b_{R}=P_{R} \cdot A_{R}
$$

onde $A b_{R}\left(\mathrm{~cm}^{3} \cdot \mathrm{s}^{-1} \cdot \mathrm{bar}^{-1}\right)$ trata-se da capacidade de absorção, $P_{R}\left(\mathrm{~cm}^{3} \cdot \mathrm{cm}^{-2} \cdot \mathrm{s}^{-1} \cdot \mathrm{bar}^{-1}\right)$ é a condutividade hidráulica e $A_{R}\left(\mathrm{~cm}^{2}\right)$ é a superfície radicular.

Em seus estudos sobre transformações na capacidade de absorção de um sistema radicular de feijoeiro, estes autores constataram que a permeabilidade do sistema radicular transformou-se de maneira complexa com a idade e incremento de área radicular. Ocorreu um rápido aumento na permeabilidade quando as raízes eram mais jovens, seguido de um decréscimo com o avanço dos dias ou idade da planta (e raízes). Gregory (1994) relatou que para situações de moderada ou alta concentração de amônio em solução foram necessários, respectivamente, 100 e $5 \mathrm{~cm}$ de raiz. $\mathrm{cm}^{-3}$ para a absorção potencial deste íon pela planta indicando que, isoladamente o comprimento radicular pode não ser um item necessariamente confiável. Desta maneira, o comprimento, massa e superfície radiculares, associados a concentrações dos 
nutrientes no solo, parece formar um complexo mais confiável e com maior probabilidade de explicar ou se correlacionar com a absorção de água e nutrientes pelo sistema radicular de plantas forrageiras.

Além disso, outros fatores internos e externos relacionados ao sistema radicular devem ser enfatizados Hopkins (1995). Os fatores internos citados por este autor são:

- estado iônico interno: se todos os sítios disponíveis da raiz para a troca inicial estiverem tomados, diminui-se a possibilidade de absorção, o mesmo ocorrendo se o suco celular estiver saturado;

- potencialidade genética: a capacidade de absorção pode variar, consideravelmente, com a espécie e dentro da espécie; espécies diferentes podem, sob mesmas condições, acumular concentrações muito diferentes de um mesmo elemento (seletividade);

- $\mathrm{pH}$ : quando se considera apenas a absorção radicular, os valores mais baixos (ácidos) de pH favorecem, como regra, a absorção de ânions, enquanto os valores mais próximos da neutralidade colaboram com a absorção de cátions.

Já os fatores externos relacionados foram:

- aeração: o oxigênio é necessário para a respiração das raízes, proporcionando energia para os processos metabólicos da planta. Entende-se, assim, a necessidade de se manter no solo condições que facilitem a penetração, o movimento e o armazenamento do ar, o que justifica o uso de práticas agronômicas, como a aração, a gradagem, a adição de corretivos, no sentido de proporcionar ao solo uma estrutura e porosidade adequadas para o desenvolvimento das plantas;

- temperatura: na faixa térmica que vai de 0 a $30^{\circ} \mathrm{C}$ geralmente aumenta a quantidade de íons absorvidos em consequência de aumentos crescentes na atividade metabólica;

- umidade e concentração de íons: embora a água seja o veículo natural dos nutrientes, a absorção destes não se dá na mesma velocidade que 
a água. Os elementos penetram na célula obedecendo à seguinte ordem decrescente:

$$
\begin{array}{ll}
\text { ânions: } & \mathrm{NO}_{3}^{-}>\mathrm{Cl}^{-}>\mathrm{SO}_{4}^{-2}>\mathrm{H}_{2} \mathrm{PO}_{4}^{-} \\
\text {cátions: } & \mathrm{NH}_{4}^{+}>\mathrm{K}^{+}>\mathrm{Mg}^{+2}>\mathrm{Ca}^{+2}
\end{array}
$$

- presença de outros íons: com relação a este fator pode-se observar três situações, sendo: I) antagonismo (a presença de um íon diminui a absorção de um segundo, evitando a toxidez deste); II) inibição (diminuição reversível ou não da absorção de um íon pela presença de outro); III) sinergismo (aumento da absorção de um íon pela presença de outro);

- presença de cálcio: o $\mathrm{Ca}^{+2}$ mantém a integridade funcional das membranas, estimulando a absorção de outros cátions, desde que não esteja em concentração muito elevada, o que poderia causar inibição de outros elementos, como o fósforo, por exemplo.

Desse modo, pode-se concluir, como apontaram Corsi et al. (2001), que a absorção de nutrientes pela planta se encontra vinculada à habilidade do solo em renovar (fator capacidade) a concentração de nutrientes em solução (fator intensidade), a partir das reservas de nutrientes trocáveis armazenadas no complexo coloidal do solo (fator quantidade). 


\section{MATERIAL E MÉTODOS}

\subsection{Local}

O experimento foi conduzido na Fazenda Areão, unidade da Escola Superior de Agricultura "Luiz de Queiroz" (ESALQ-USP), em Piracicaba-SP (2242'30" Latitude Sul ; 47³8'30" Longitude Oeste), em área de pastagem de capim Tanzânia (Panicum maximum), irrigada através de sistema de pivô central.

\section{2 Área experimental}

Os trabalhos foram desenvolvidos em área irrigada de 4,8 hectares. $O$ delineamento experimental foi o de blocos ao acaso com quatro repetições e três tratamentos, que se constituíram nos níveis de resíduo pós pastejo de 1000, 2500 e 4000 kg MSV.ha $^{-1}$.

O resíduo pós pastejo foi determinado em relação à lotação animal. A partir de oferta inicial de forragem medida através de coleta de $5 \mathrm{~m}^{2}$ por piquete ( 5 quadrados de $1 \mathrm{~m} \times 1 \mathrm{~m}$ ), calculava-se a taxa de lotação de modo que ao final do período de pastejo (3 dias) fosse possível obter o resíduo pós pastejo planejado. A partir desta metodologia, os resíduos médios finais obtidos foram: T1 = $1518 \mathrm{~kg} \mathrm{MSV} \cdot \mathrm{ha}^{-1}$, T2 = $2902 \mathrm{~kg} \mathrm{MSV} \cdot \mathrm{ha}^{-1}, \mathrm{~T} 3=4220 \mathrm{~kg} \mathrm{MSV} \cdot \mathrm{ha}^{-1}$.

A divisão dos piquetes foi feita através de cerca elétrica, sendo a divisão feita na forma de "fatias de pizza" com 12 piquetes para cada 
tratamento, sendo o manejo destes piquetes realizado com período de ocupação e descanso fixos de 3 e 33 dias, respectivamente.

Antes da formação da pastagem, o solo recebeu correções (calagem, fosfatagem e potassagem) para se atingir valores próximos de: saturação por bases, $80 \%$; fósforo, $25 \mathrm{mg} \cdot \mathrm{dm}^{-3}$; potássio, $5 \%$ da $\mathrm{T}$ (capacidade de troca de cátions). Durante o período do estudo as parcelas pastejadas recebiam 80 kg.ha ${ }^{-1}$ de $\mathrm{N}, 13 \mathrm{~kg} \cdot \mathrm{ha}^{-1}$ de $\mathrm{P}_{2} \mathrm{O}_{5}$ e $80 \mathrm{~kg} \cdot \mathrm{ha}^{-1}$ de $\mathrm{K}_{2} \mathrm{O}$, dentro de 3 dias após cada pastejo.

\subsection{Amostragens e parâmetros a serem determinados:}

\subsubsection{Experimento 1}

Nesta pesquisa foram realizadas amostragens do sistema radicular da planta forrageira à distância de $10 \mathrm{~cm}$ da borda da touceira através de trado/sonda de $4 \mathrm{~cm}$ de diâmetro (Figura 1). As dimensões deste amostrador foram baseadas em relatos de Vogt \& Persson (1991) em referência a amostragens de plantas com diâmetros radiculares relativamente pequenos, como gramíneas forrageiras. Estes autores recomendaram a utilização de sondas com até $6 \mathrm{~cm}$ de diâmetro pelo fato destas plantas apresentarem número suficiente de raízes e distribuição ao acaso para serem quantificadas por equipamento com este perfil. Além disso, alguns trabalhos com plantas forrageiras tropicais utilizaram aparelho semelhante para amostragens desta natureza (Rodrigues \& Cádima-Zevallos, 1991), possibilitando um aumento do número de amostragens e minimizando o efeito de amostragens destrutivas.

Foram analisados peso seco, comprimento e área radicular através de um software, modelo DELTA T SCAN, de análise de imagens de raízes (Figura 2). 


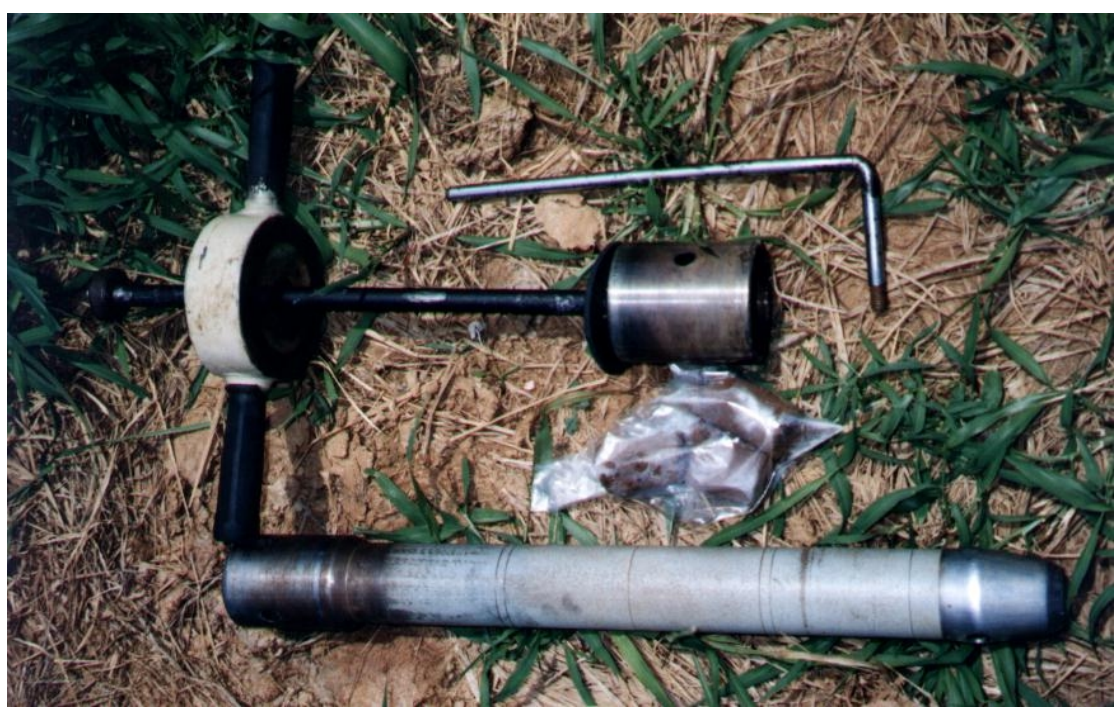

Figura 1 - Trado/sonda utilizado para coleta de amostras

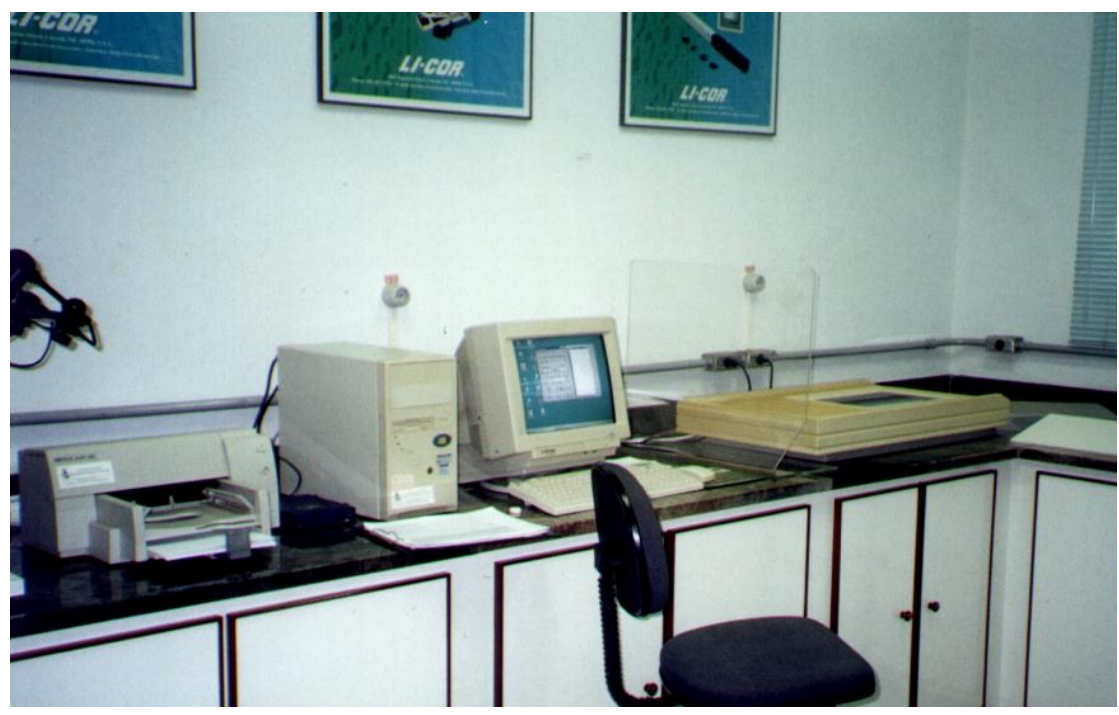

Figura 2 - Scanner de mesa acoplado ao Software Modelo DELTA - T para análise digital de raízes 
Também foi realizada separação e pesagens de raízes vivas (ativas) e mortas do sistema radicular através de análise visual, conforme indicado por Tennant (1975). Esta análise visual relacionava coloração branca a bege claro para as raízes vivas e coloração marrom para as raízes mortas.

As amostras foram coletadas para os três tratamentos (níveis de resíduo pós pastejo de 1000, 2500 e 4000 kg MSV.ha ${ }^{-1}$ ), em duas profundidades (0-20 e 20-40 cm), e a cada dois ciclos de pastejo eram realizadas cinco coletas, entre o final de outubro de 1999 e meados de maio de 2000. Uma coleta foi realizada seis dias antes do pastejo (correspondendo a 30 dias pós pastejo de um ciclo anterior) e quatro coletas após o pastejo (3, 12, 21 e 30 dias pós pastejo). Na totalidade foram analisados três ciclos de pastejo para este estudo.

Neste processo as raízes foram separadas do solo com auxílio de uma lavadora automática de raízes, modelo DELTA T (Figuras 3 e 4), e posteriormente secas em estufa de circulação forçada a $65^{\circ} \mathrm{C}$ por 48 horas para que os parâmetros pudessem ser quantificados. 


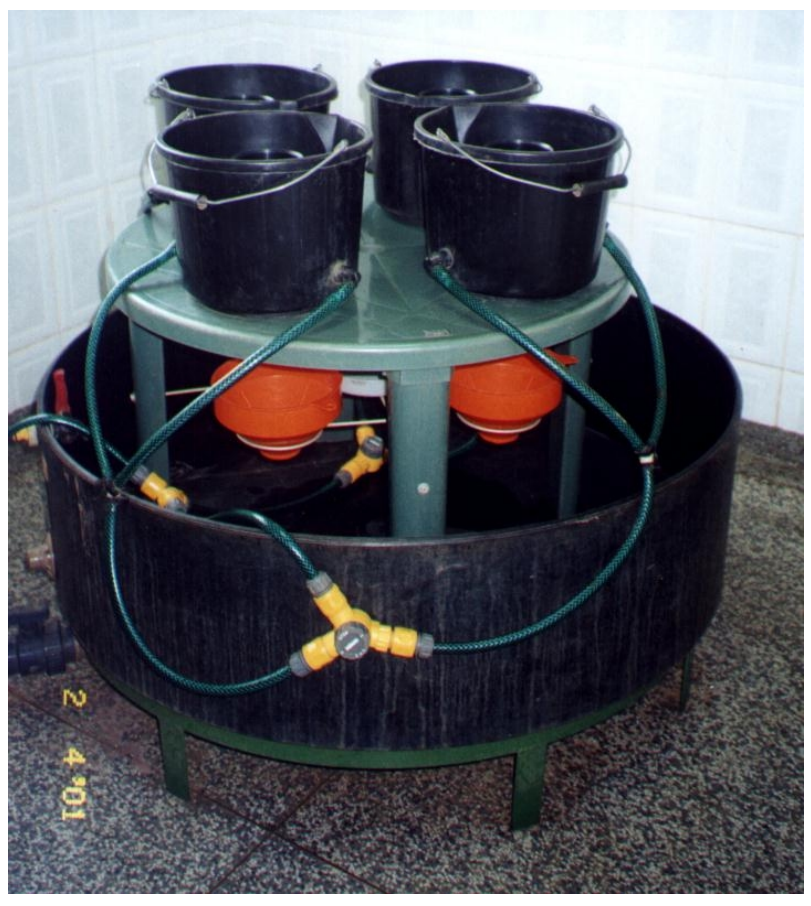

Figura 3 - Lavadora automática de raízes

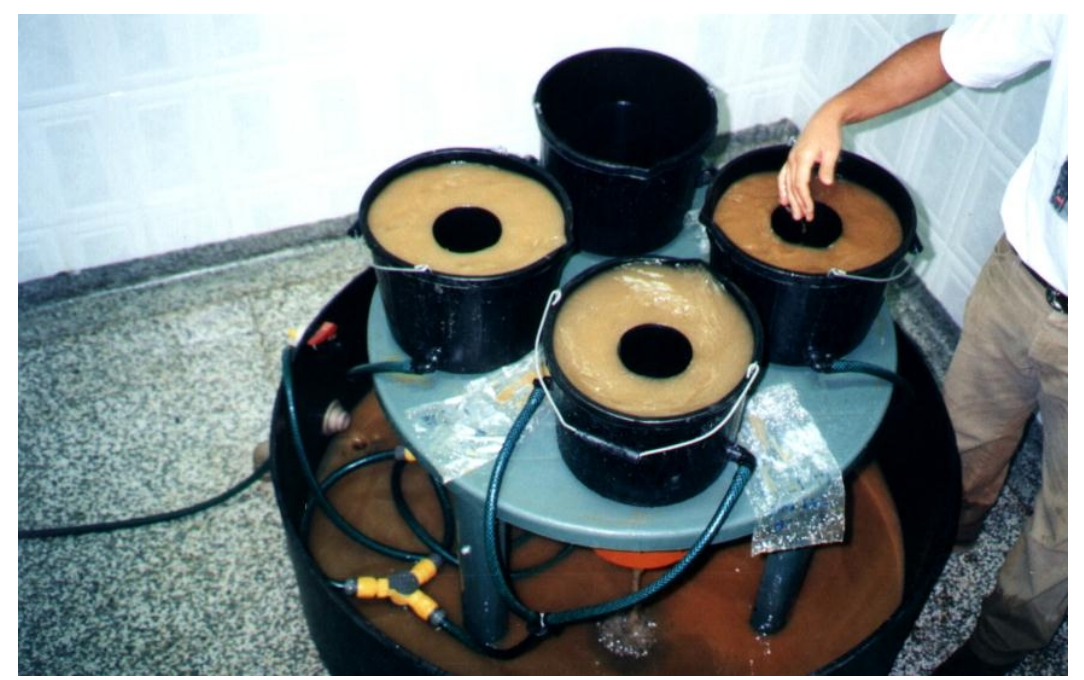

Figura 4 - Esquema de funcionamento da lavadora de raízes 
Os processos de lavagem e medição das raízes foram realizados no Departamento de Botânica da ESALQ-USP, Laboratório de Plantas Cultivadas sob Condições de Estresse.

\subsubsection{Experimento 2}

Neste trabalho foram feitas medições do crescimento do sistema radicular do capim utilizando covas preenchidas com areia grossa, conforme indicado por Mathew (1992).

Estas covas cilíndricas de $4 \mathrm{~cm}$ de diâmetro por $20 \mathrm{~cm}$ de profundidade foram preenchidas, imediatamente após o pastejo, com areia de construção e após 3, 12, 21 e 30 dias foram amostradas para determinação do desenvolvimento radicular nos três resíduos pós pastejo estudados, ou seja,

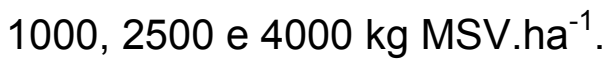

As covas foram instaladas eqüidistantes uma da outra a cada $0,50 \mathrm{~m}$, através de uma linha transecta disposta no sentido de atravessar o piquete em linha diagonal. Assim, quatro amostras foram retiradas de cada bloco a cada 9 dias, ou seja, aos $3,12,21$ e 30 dias pós pastejo para cada tratamento de modo que pudessem formar uma repetição.

A determinação da recuperação do sistema radicular após as diferentes desfolhas através das medições de crescimento radicular também foram feitas através do software DELTA T SCAN de análise de imagens de raízes, no Departamento de Botânica da ESALQ-USP, Laboratório de Plantas Cultivadas sob Condições de Estresse.

Neste caso, as análises foram realizadas em dois ciclos de pastejo, ou seja, dezembro do ano 1999 e fevereiro de 2000. 


\subsection{Análise estatística}

Os dados de massa, comprimento e área de raízes foram analisados também através do PROC GLM do SAS 6.11 (1991), assim como o teste para distribuição normal dos erros, sendo as transformações de dados realizadas, quando necessárias, através do SAS ASSIST.

A literatura existente para o estudo de sistemas radiculares de plantas forrageiras tropicais, apesar de escassa, mostra variabilidade muito alta (Bono et al., 2000; Carvalho, 1999; Rodrigues \& Cádima-Zevallos, 1991), sendo freqüente a existência de coeficientes de variação da ordem de $50 \%$, dificilmente gerando significância entre tratamentos pela estatística tradicional.

Desta maneira foram propostos padrões menos ortodoxos de significância na análise dos resultados. Considerou-se o nível de $7 \%$ de significância como significativo e até $20 \%$ como tendência, para os valores de probabilidade do teste $\mathrm{F}$, sendo a significância até $7 \%$ ilustrada nas tabelas de discussão com letras maiúsculas e a significância até $20 \%$, com letras minúsculas. 


\section{RESULTADOS E DISCUSSÃO}

\subsection{EXPERIMENTO I - Dinâmica do sistema radicular do capim Tanzânia no solo}

\subsubsection{Efeito de tratamentos}

A dinâmica de crescimento das raízes totais do capim Tanzânia na profundidade $0-40 \mathrm{~cm}$ foi estudada para massa, comprimento e superfície radiculares no período que compreendeu o final da primavera de 1999, se estendendo até meados do outono de 2000, e pode ser observada na Tabela 1.

A análise dos resultados não indica diferenças significativas ( $\mathrm{Pr}>7 \%$ ) para os parâmetros avaliados, mostrando apenas tendências para diferenças na massa de raízes para o final do período de primavera e para os resultados referentes à superfície de raízes tanto para primavera como para o outono.

Respostas semelhantes foram encontradas por Rodrigues \& CadimaZevallos (1991) estudando o efeito da intensidade de pastejo sobre o sistema radicular de Brachiaria humidicola. Nesta situação, os autores não encontraram diferenças significativas para a densidade de raízes até $100 \mathrm{~cm}$ de profundidade entre as taxas de lotação de 2,2 e 4,4 cabeças.ha $^{-1}$, entretanto a maior taxa de lotação gerou densidades numericamente menores. 
Tabela 1. Desenvolvimento radicular do capim Tanzânia irrigado para diferentes resíduos pós pastejo (T1 - $1000 \mathrm{~kg} \mathrm{MSV.ha-1}^{-1}$; T2 - 2500 kg MSV.ha- ${ }^{-1}$; T3 - 4000 kg MSV.ha ${ }^{-1}$ ) entre novembro de 1999 e maio de 2000 , para a profundidade $0-40 \mathrm{~cm}$.

\begin{tabular}{|c|c|c|c|c|c|}
\hline & \multicolumn{3}{|c|}{ tratamentos } & \multirow{2}{*}{ EPM } & \multirow{2}{*}{$\operatorname{Pr}=F$} \\
\hline & T1 & T2 & T3 & & \\
\hline \multicolumn{6}{|c|}{$\begin{array}{l}\text { massa de raízes } \\
\left(\mathrm{mg} / \mathrm{cm}^{3} \text { de solo }\right)\end{array}$} \\
\hline primavera & $0,37 \mathrm{~b}$ & $0,45 a b$ & $0,49 a$ & 0,04 & 0,1453 \\
\hline verão & 0,58 & 0,64 & 0,55 & 0,08 & 0,6122 \\
\hline outono & 0,56 & 0,65 & 0,67 & 0,08 & 0,6058 \\
\hline \multicolumn{6}{|c|}{$\begin{array}{l}\text { comprimento de raízes } \\
\left(\mathrm{cm}^{\mathrm{c}} \mathrm{cm}^{3} \text { solo }\right)\end{array}$} \\
\hline primavera & 4,77 & 5,70 & 5,90 & 0,58 & 0,3865 \\
\hline verão & 6,13 & 6,56 & 5,92 & 0,89 & 0,7266 \\
\hline outono & 6,16 & 6,67 & 8,08 & 0,76 & 0,2363 \\
\hline \multicolumn{6}{|c|}{$\begin{array}{l}\text { superfície de raízes } \\
\left(\mathrm{cm}^{2} / \mathrm{cm}^{3} \text { solo }\right)\end{array}$} \\
\hline primavera & $906,70 \mathrm{~b}$ & $1089,62 \mathrm{ab}$ & 1165,99 a & 94,33 & 0,1918 \\
\hline verão & 1227,62 & 1346,69 & 1198,50 & 163,68 & 0,6844 \\
\hline outono & $1203,68 b$ & $1331,99 a b$ & $1556,73 a$ & 124,77 & 0,1845 \\
\hline
\end{tabular}

EPM: erro padrão da média

$\mathrm{Pr}=\mathrm{F}$ : probabilidade $\alpha$ de haver efeito significativo entre os tratamentos no ciclo de pastejo.

a, b: médias na mesma linha seguidas de letras minúsculas distintas diferem entre si a $20 \%$ de significância.

O isolamento das raízes vivas e pesagem desta fração possibilitou a visualização de diferenças significativas para o primeiro período analisado (Tabela 2), com a desfolha mais pesada provocando diminuição da massa de raízes. Porém, quando estratificamos o perfil de amostragem em duas profundidades (Tabelas 3 e 4), pode-se verificar que o tratamento com resíduo

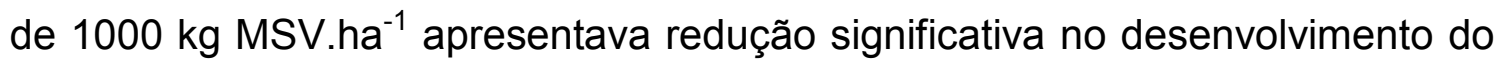


sistema radicular na profundidade de $0-20 \mathrm{~cm}$ durante a primeira amostragem (primavera) e tendências de redução no sistema radicular durante a amostragem de verão, não se diferenciando, entretanto do tratamento de maior resíduo (4000 kg MSV.ha-1).

Tabela 2. Massa de raízes vivas do capim Tanzânia irrigado para diferentes resíduos pós pastejo (T1 - $1000 \mathrm{~kg} \mathrm{MSV.ha-1}^{-1}$ T2 - $2500 \mathrm{~kg} \mathrm{MSV.ha}{ }^{-}$ 1; T3 - 4000 kg MSV.ha ${ }^{-1}$ ) entre novembro de 1999 e maio de 2000, na profundidade $0-40 \mathrm{~cm}$.

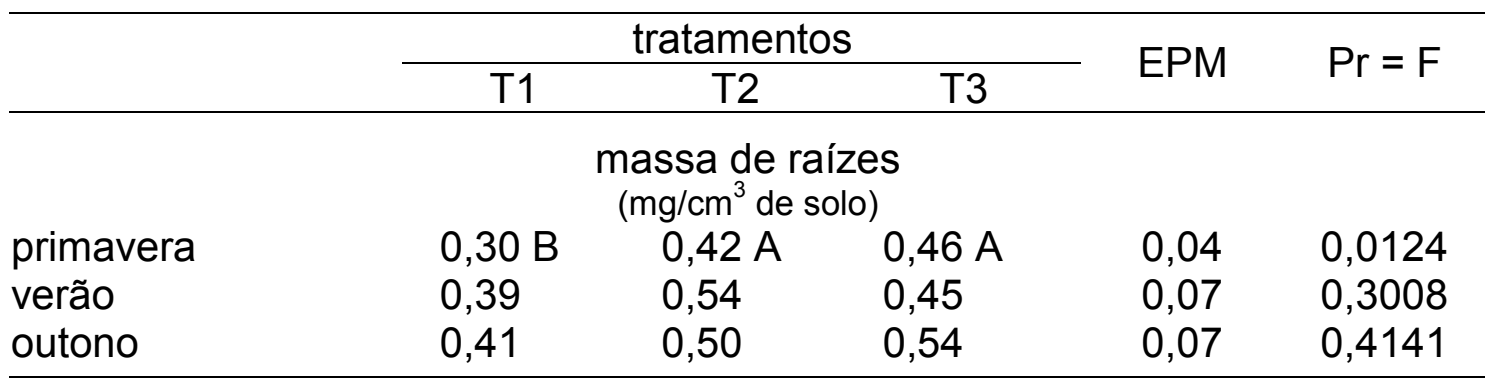

EPM: erro padrão da média

$\operatorname{Pr}=\mathrm{F}$ : probabilidade a de haver efeito significativo entre os tratamentos no ciclo de pastejo.

A, B: médias na mesma linha seguidas de letras maiúsculas distintas diferem entre si a $7 \%$ de significância.

A comparação entre a massa de raízes totais (Tabela 1) e a massa de raízes vivas (Tabela 2) não mostrou diferença nas análises, entretanto os valores de $\operatorname{Pr}$ chegaram mais perto de níveis significativos quando se considerou as raízes vivas. Este dado sugere a utilização da metodologia de análise de raízes vivas, uma vez que, obviamente, raízes mortas não participam dos processos de absorção, ficando a solução do solo apenas retida no apoplasto das raízes mortas (Taiz \& Zeiger, 1991). Vogt \& Persson (1991) suportam a idéia, relatando certa facilidade em se distinguir as raízes vivas de 
raízes mortas e assim se obtém melhor enfoque para uma análise mais direcionada.

Tabela 3. Massa de raízes vivas do capim Tanzânia irrigado para diferentes

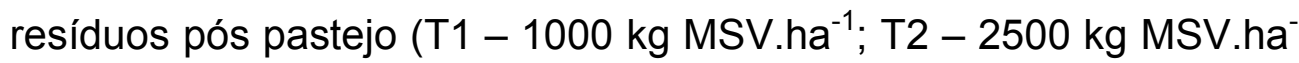

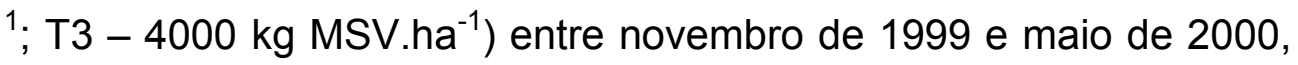
na profundidade $0-20 \mathrm{~cm}$.

\begin{tabular}{|c|c|c|c|c|c|}
\hline & \multicolumn{3}{|c|}{ tratamentos } & \multirow{2}{*}{ EPM } & \multirow{2}{*}{$\mathrm{Pr}=\mathrm{F}$} \\
\hline & T1 & $\mathrm{T} 2$ & T3 & & \\
\hline \multicolumn{6}{|c|}{$\begin{array}{l}\text { massa de raízes } \\
\left(\mathrm{mg} / \mathrm{cm}^{3} \text { de solo }\right)\end{array}$} \\
\hline primavera & $0,41 \mathrm{~B}$ & $0,60 \mathrm{~A}$ & $0,66 \mathrm{~A}$ & 0,06 & 0,0089 \\
\hline verão & $0,58 \mathrm{~b}$ & $0,86 a$ & $0,65 \mathrm{~b}$ & 0,10 & 0,1471 \\
\hline outono & 0,64 & 0,80 & 0,84 & 0,10 & 0,4423 \\
\hline
\end{tabular}

EPM: erro padrão da média

$\operatorname{Pr}=\mathrm{F}$ : probabilidade $\alpha$ de haver efeito significativo entre os tratamentos no ciclo de pastejo.

A, B: médias na mesma linha seguidas de letras maiúsculas distintas diferem entre si a $7 \%$ de significância.

a,b: médias na mesma linha seguidas de letras minúsculas distintas diferem entre si a $20 \%$ de significância.

As Figuras 5 e 6 ilustram as percentagens de raízes vivas e mortas, podendo-se visualizar a maior mortalidade para o tratamento submetido ao

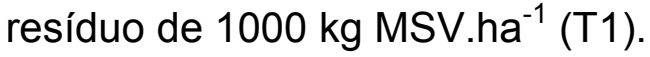

Vários trabalhos relacionados a medições de raízes relatam que a primeira camada de solo seria a responsável pela maior proporção do volume radicular (Carvalho, 1999; Mathew, 1992; Rodrigues et al., 2001; Rodrigues \& Cádima-Zevallos, 1991; Bono et al., 2000). Em concordância com a literatura, a análise das Tabelas 3 e 4 permite o levantamento de informações que nos induzem também a dar maior relevância à camada de 0-20 cm, uma vez que esta representou na média das três estações $74 \%, 78 \%$ e $75 \%$ da massa de raízes vivas para $\mathrm{T} 1, \mathrm{~T} 2$, e $\mathrm{T} 3$, respectivamente. 
Tabela 4. Massa de raízes vivas do capim Tanzânia irrigado para diferentes resíduos pós pastejo (T1 - $1000 \mathrm{~kg} \mathrm{MSV.ha}^{-1} ; \mathrm{T} 2$ - $2500 \mathrm{~kg} \mathrm{MSV.ha^{- }}$ 1; T3 - 4000 kg MSV.ha ${ }^{-1}$ ) entre novembro de 1999 e maio de 2000, na profundidade $20-40 \mathrm{~cm}$.

\begin{tabular}{|c|c|c|c|c|c|}
\hline & \multicolumn{3}{|c|}{ tratamentos } & \multirow{2}{*}{ EPM } & \multirow{2}{*}{$\operatorname{Pr}=F$} \\
\hline & T1 & $\mathrm{T} 2$ & T3 & & \\
\hline \multicolumn{6}{|c|}{$\begin{array}{c}\text { massa de raízes } \\
\left(\mathrm{mg} / \mathrm{cm}^{3} \text { de solo }\right)\end{array}$} \\
\hline primavera & 0,20 & 0,20 & 0,25 & 0,02 & 0,2460 \\
\hline verão & 0,19 & 0,22 & 0,23 & 0,05 & 0,7609 \\
\hline outono & 0,18 & 0,21 & 0,25 & 0,05 & 0,3684 \\
\hline
\end{tabular}

EPM: erro padrão da média

$\operatorname{Pr}=\mathrm{F}$ : probabilidade $\alpha$ de haver efeito significativo entre os tratamentos no ciclo de pastejo.
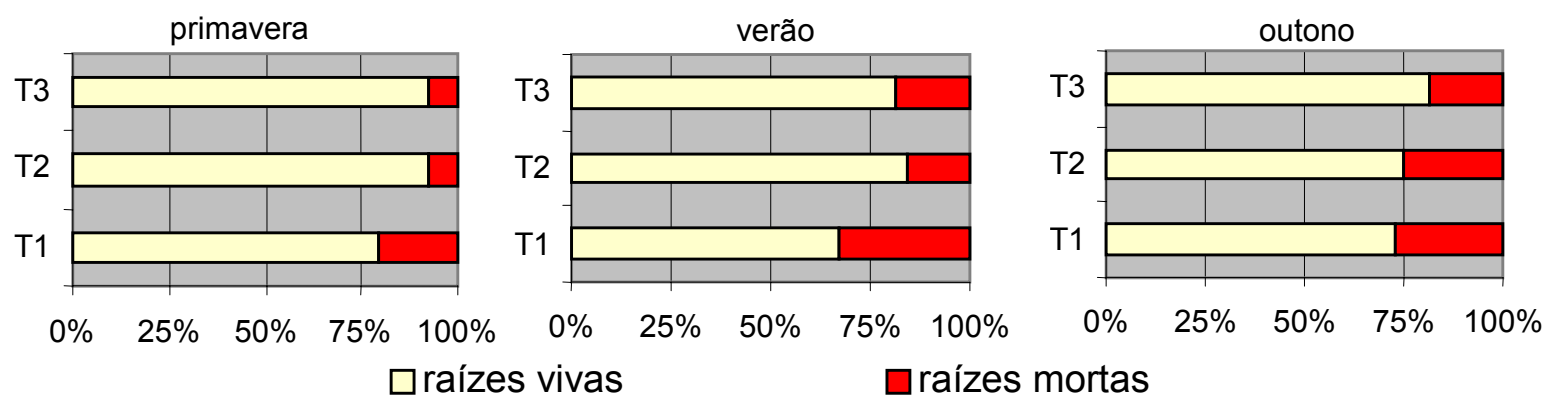

Figura 5 - Porcentagem de raízes vivas e mortas do capim Tanzânia irrigado para diferentes resíduos pós pastejo (T1 - $1000 \mathrm{~kg} \mathrm{MSV.ha-1;} \mathrm{T2} \mathrm{-}$

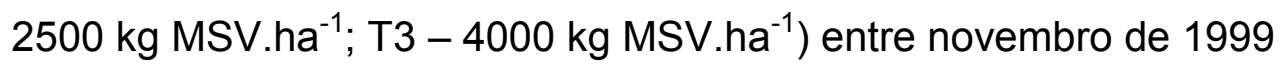
e maio de 2000 , na profundidade $0-20 \mathrm{~cm}$. 

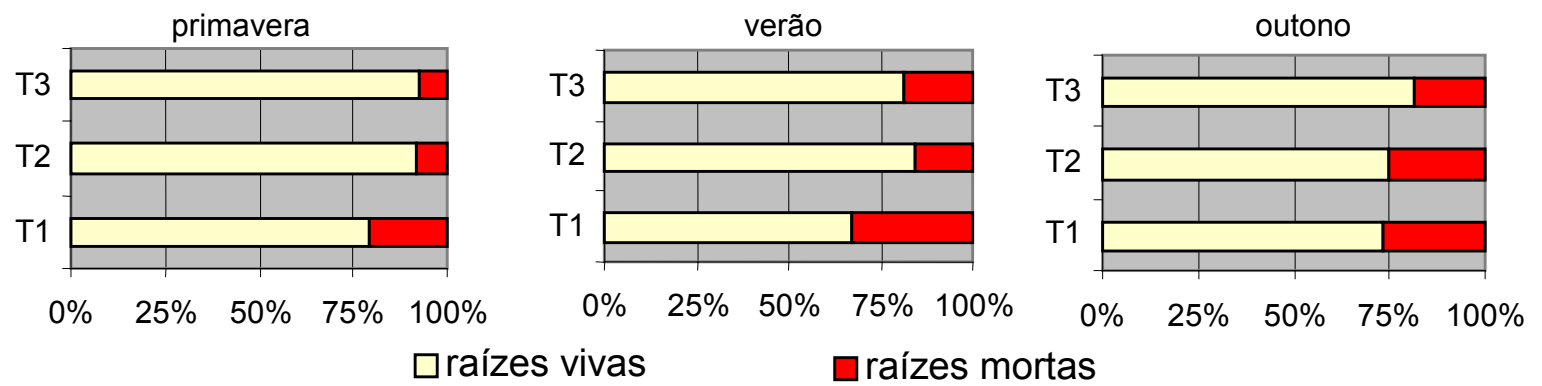

Figura 6 - Porcentagem de raízes vivas e mortas do capim Tanzânia irrigado para diferentes resíduos pós pastejo (T1 - $1000 \mathrm{~kg} \mathrm{MSV.ha}^{-1}$; T2 $2500 \mathrm{~kg} \mathrm{MSV} . \mathrm{ha}^{-1} ;$ T3 - $4000 \mathrm{~kg} \mathrm{MSV} . \mathrm{ha}^{-1}$ ) entre novembro de 1999 e maio de 2000 , na profundidade $20-40 \mathrm{~cm}$.

Estudos realizados por Mathew \& Kemball (1997) com carbono radioativo também mostraram menor atividade do sistema radicular em profundidade. Estes autores observaram maior desenvolvimento de massa e comprimento radiculares para as ramificações do eixo principal mais próximas à superfície do solo, como resultado da maior alocação de carbono para estas regiões do sistema radicular. Com isso ressaltaram a atividade de raízes novas e posicionadas nas primeiras posições nodais como fundamental para o entendimento da dinâmica radicular.

A partir dessas informações, podemos iniciar uma especulação sobre a possibilidade de amostragens apenas nas camadas mais superficiais do solo $(0-20 \mathrm{~cm})$ para estudos de desenvolvimento do sistema radicular. A Tabela 4 suporta esta hipótese, uma vez que indica não haver diferenças para efeito de tratamentos entre os três resíduos de forragem avaliados para massa de raízes vivas na profundidade $20-40 \mathrm{~cm}$.

Este novo padrão de amostragens, com coletas de raízes apenas na camada de $0-20 \mathrm{~cm}$ de solo, seria interessante tanto por facilitar a coleta de amostras como por permitir o aumento no número destas, buscando diminuir a 
variabilidade dos dados que é excessivamente alta para estudos com raízes (Vogt \& Bloomfield, 1991).

A Tabela 5 mostra a dinâmica das raízes totais do capim Tanzânia na camada 0-20 cm para massa, comprimento e superfície de raízes. No entanto nesta condição de análise (raízes totais), não se observou diferença ao nível de $7 \%$.

Tabela 5. Desenvolvimento radicular do capim Tanzânia irrigado para

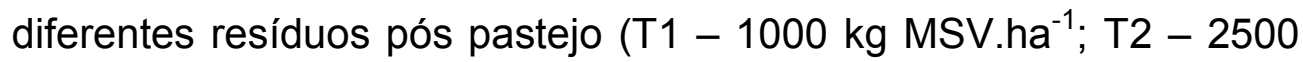
kg MSV.ha- ${ }^{-1}$; T3 - 4000 kg MSV.ha ${ }^{-1}$ ) entre novembro de 1999 e maio de 2000 , na profundidade $0-20 \mathrm{~cm}$.

\begin{tabular}{|c|c|c|c|c|c|}
\hline & \multicolumn{3}{|c|}{ tratamentos } & \multirow{2}{*}{ EPM } & \multirow{2}{*}{$\operatorname{Pr}=\mathrm{F}$} \\
\hline & T1 & T2 & T3 & & \\
\hline \multicolumn{6}{|c|}{$\begin{array}{c}\text { massa de raízes } \\
\left(\mathrm{mg} / \mathrm{cm}^{3} \text { de solo }\right)\end{array}$} \\
\hline primavera & $0,51 \mathrm{~b}$ & 0,65 a & $0,71 \mathrm{a}$ & 0,07 & 0,1139 \\
\hline verão & 0,89 & 1,02 & 0,80 & 0,12 & 0,2399 \\
\hline outono & 0,89 & 1,05 & 1,19 & 0,14 & 0,6036 \\
\hline \multicolumn{6}{|c|}{$\begin{array}{l}\text { comprimento de raízes } \\
\left(\mathrm{cm} / \mathrm{cm}^{3} \mathrm{solo}\right)\end{array}$} \\
\hline primavera & 6,51 & 8,56 & 8,60 & 1,10 & 0,3623 \\
\hline verão & 9,80 & 10,55 & 9,06 & 1,50 & 0,6693 \\
\hline outono & $9,58 \mathrm{~b}$ & $10,76 \mathrm{ab}$ & $13,02 \mathrm{a}$ & 1,19 & 0,1734 \\
\hline \multicolumn{6}{|c|}{$\begin{array}{l}\text { superfície de raízes } \\
\left(\mathrm{cm}^{2} / \mathrm{cm}^{3} \text { solo }\right)\end{array}$} \\
\hline primavera & 1341,78 & 1619,49 & 1722,15 & 165,42 & 0,2922 \\
\hline verão & 1950,41 & 2194,87 & 1833,09 & 264,34 & 0,5305 \\
\hline outono & 1864,13 & 2171,74 & 2332,18 & 184,99 & 0,2458 \\
\hline
\end{tabular}

EPM: erro padrão da média

$\operatorname{Pr}=\mathrm{F}$ : probabilidade $\alpha$ de haver efeito significativo entre os tratamentos no ciclo de pastejo.

a,b: médias na mesma linha seguidas de letras minúsculas distintas diferem entre si a $20 \%$ de significância. 
Tal situação nos indica que os estudos sobre dinâmica do sistema radicular de plantas forrageiras envolvendo avaliações sobre massa, comprimento e superfície radiculares devem analisar separadamente as frações vivas e mortas destas espécies.

A avaliação da massa de raízes mortas para as diferentes intensidades de pastejo mostrou alterações significativas para, praticamente, todas as situações analisadas (Tabela 6). Neste caso, $79 \%, 83 \%$ e $84 \%$ da massa de raízes mortas foram encontrados na profundidade $0-20 \mathrm{~cm}$ para $\mathrm{T} 1$, T2 e T3, respectivamente. Esta informação ratifica a importância da primeira camada de solo para estudos sobre a dinâmica do sistema radicular, entretanto discorda de Matthew \& Kemball (1997) que apontam maior mortalidade para raízes que crescem em fitômeros mais distantes da coroa da planta, em função de receberem menores quantidades de fotoassimilados.

Os resultados parecem indicar maior sensibilidade do tratamento desfolhado com maior intensidade (T1) em relação à perda da atividade de seu sistema radicular. Esta situação permite inferir sobre uma maior necessidade da planta forrageira quando manejada com resíduo pós pastejo de $1000 \mathrm{~kg}$ MSV.ha" ${ }^{-1}$ em utilizar suas reservas para recuperação de área foliar, disponibilizando praticamente $30 \%$ da massa radicular durante a primavera em relação aos tratamentos mais lenientes (Tabela 3). Respostas semelhantes foram encontradas por Donaghy \& Fulkerson (1998), estudando o sistema radicular e a rebrota de azevém perene em casa de vegetação. Nesta situação os autores verificaram menor quantidade de raízes e concentração de carboidratos quando a planta era submetida a desfolhas mais frequentes e intensas, com o inverso ocorrendo quando esta era submetida a uma desfolha mais leve e com intervalo de tempo maior. Já Thornton \& Millard (1993) verificaram que um incremento na severidade de desfolha resultou em decréscimo da massa radicular associada a uma diminuição na absorção de nitrogênio, de 0,54 para $0,14 \mathrm{mg} \mathrm{N}$.(semana) ${ }^{-1}$ (planta) ${ }^{-1}$ em azevém perene quando a planta foi repetidamente cortada a 8 e $4 \mathrm{~cm}$ respectivamente. 
Tabela 6. Massa de raízes mortas do capim Tanzânia irrigado para diferentes

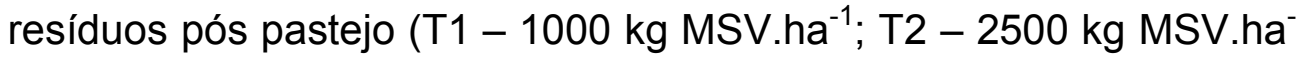
1; T3 - 4000 kg MSV.ha ${ }^{-1}$ ) entre novembro de 1999 e maio de 2000, nas profundidades $0-20$ e $20-40 \mathrm{~cm}$.

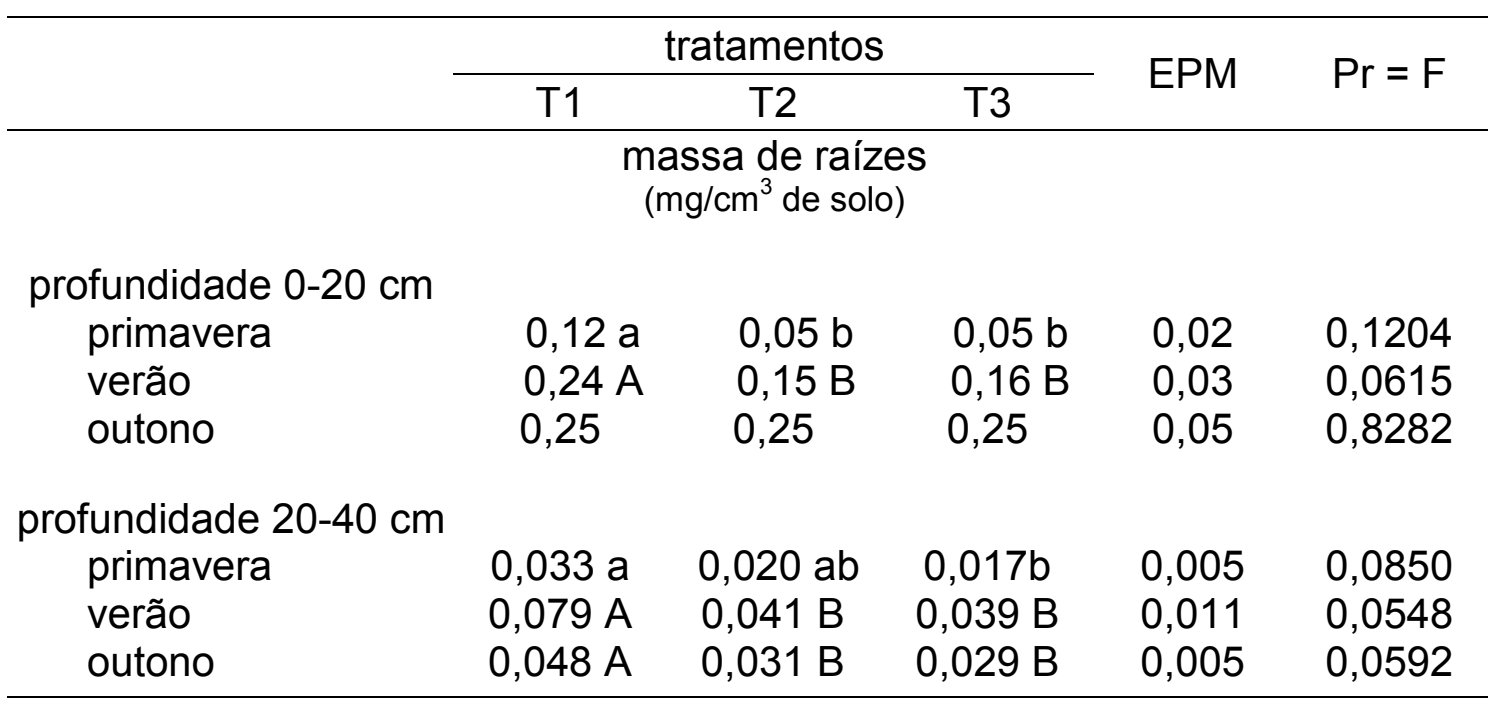

EPM: erro padrão da média

$\mathrm{Pr}=\mathrm{F}$ : probabilidade a de haver efeito significativo entre os tratamentos no ciclo de pastejo.

A, B: médias na mesma linha seguidas de letras maiúsculas distintas diferem entre si a $7 \%$ de significância.

a,b: médias na mesma linha seguidas de letras minúsculas distintas diferem entre si a $20 \%$ de significância.

Assim, uma pastagem submetida excessivamente a um manejo mais intenso e freqüente de desfolha poderá perder vigor de rebrota em função do resíduo pós pastejo não se mostrar suficiente para reposição da área foliar. Desse modo, poderá ocorrer a degradação desta em conseqüência de rebrotas menos vigorosas, em consequência do decréscimo do sistema radicular, associado a fatores de fertilidade do solo e disponibilidade hídrica.

Com a morte e diminuição do sistema radicular, o raio de ação da planta para obtenção de água e nutrientes do solo é reduzido o que, para ser compensado, exigiria maior concentração de água e nutrientes num menor 
volume de solo. Gregory (1994) demonstrou este fato ao evidenciar a importância do comprimento de raízes para taxas máximas de absorção do amônio em solução, quando foram exigidos 100 e $5 \mathrm{~cm}$ de raízes para cada $\mathrm{cm}^{3}$ de solo quando a disponibilidade deste íon no solo foi baixa e alta, respectivamente.

O comprimento do sistema radicular mostrou ser um parâmetro com menores variações do que a massa e a superfície das raízes para avaliações dos efeitos da intensidade do pastejo. Nas Tabelas 1 e 5 não se verificou diferenças em relação ao comprimento de raízes, exceto para a avaliação efetuada no outono (Tabela 5) quando houve tendência de redução do

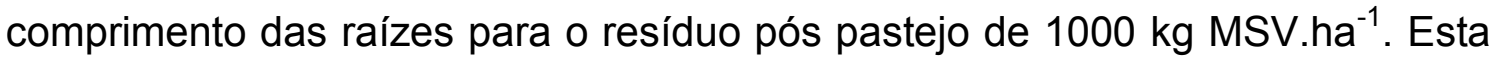
constatação se assemelha aos resultados obtidos vários autores no Brasil para estudos com sistemas radiculares de gramíneas forrageiras (Rodrigues \& Cádima-Zevallos, 1988; Amaral, 1998; Corrêa et al. 2000), sinalizando uma possível revisão de metodologias de amostragens e/ou interpretação dos resultados.

Para primavera e outono valores numericamente crescentes para desenvolvimento radicular foram encontrados, de maneira que T3>T2>T1 (Tabelas 1 e 5). Apenas para os meses de verão, menor diferenciação numérica foi encontrada, provavelmente devido às características climáticas nesta época (Sentelhas, 2000), principalmente temperatura e luminosidade, além da água, gerando à planta melhores condições de se adaptar a condições de estresse através de maiores taxas fotossintéticas. Trabalho realizado por Mello et al. (2001) na mesma área experimental desse estudo confirmam a proposição, indicando aumentos crescentes nas taxas fotossintéticas do capim Tanzânia irrigado até a temperatura de $35^{\circ} \mathrm{C}$.

Tosi (1999) estudando o capim Tanzânia em São Carlos - SP também determinou que o maior acúmulo de massa foi observado durante os meses de janeiro e fevereiro, mesmo quando o regime pluviométrico não foi tão favorável quando comparado aos demais meses da época das chuvas. 
Desta maneira, podemos inferir sobre uma maior plasticidade morfofisiológica da planta forrageira em suportar pastejos intensos nestes meses do ano, sem comprometimento do sistema radicular.

\subsubsection{Efeitos de épocas no mesmo ciclo de pastejo}

A dinâmica do crescimento do sistema radicular do capim Tanzânia irrigado dentro de um mesmo ciclo de pastejo foi avaliada para toda a base de dados. Independentemente dos tratamentos impostos, foi analisado o efeito da intensidade de pastejo em função dos dias após o pastejo. A Tabela 7 ilustra a resposta do sistema radicular para uma data antes do pastejo, (equivalente a 30 dias pós pastejo do ciclo anterior) e quatro períodos pós pastejo: 3, 12, 21 e 30 dias.

O total de raízes avaliadas no outono, através do acúmulo de massa, do comprimento e da superfície das raízes foi maior a partir de 12 dias após o pastejo, exceto para acúmulo de massa que apresentou maior desenvolvimento a partir de 21 dias pós pastejo, indicando a retomada do crescimento radicular para os três parâmetros analisados somente a partir da terceira semana após o pastejo. 


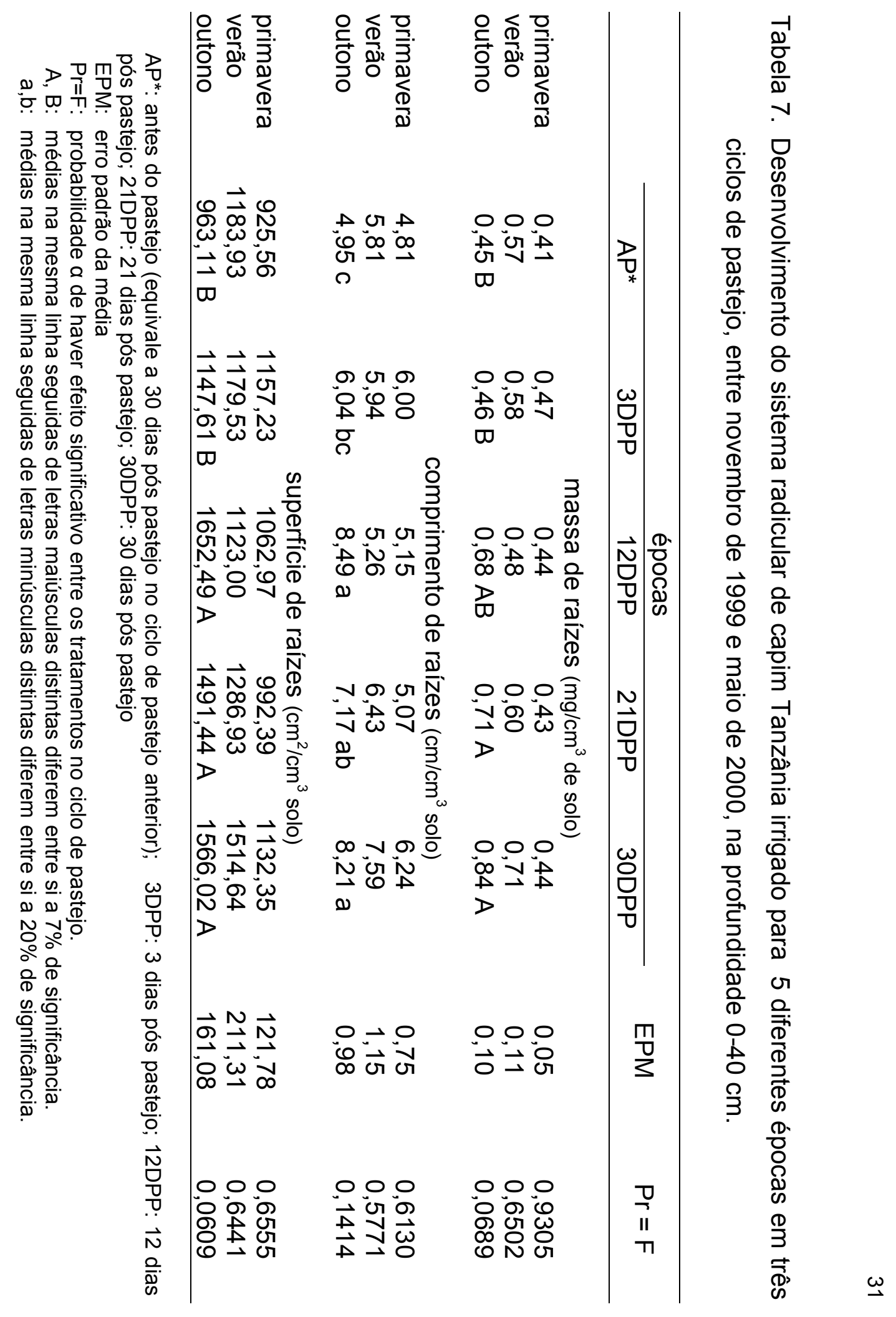


Para os períodos de primavera e verão não ficaram evidenciadas diferenças entre as épocas dentro de cada ciclo de pastejo considerando os parâmetros estudados para avaliação do desenvolvimento do sistema radicular. Este fato reflete a fraca evidência desta avaliação para o estudo da dinâmica radicular dentro de um mesmo ciclo de pastejo ou que o desenvolvimento do sistema radicular sofre menores variações na primavera e verão em relação ao outono.

Do mesmo modo, Mathew (1992) estudando o turnover radicular do azevém, mostrou grande variação sazonal, porém não encontrou diferenças significativas para esta variável, mesmo quando a comparação foi realizada entre pastejo leniente ou severo, com longevidade radicular mínima de 160 dias para o tratamento sob pastejo mais intenso.

Mesmo quando a análise relacionou as raízes vivas (Tabela 8 ) e as raízes mortas (Tabela 9) do capim Tanzânia irrigado nas profundidades 0-20 e 20-40 cm, apenas algumas tendências foram observadas. Os resultados observados na Tabela 7 com relação à massa radicular são melhor explicados pelo crescimento de raízes vivas na camada $0-20 \mathrm{~cm}$ após 21 dias pós pastejo (Tabela 8).

Estes resultados retratam a plasticidade do desenvolvimento radicular, com longevidade de certa maneira imprevisível, conforme descrito por Fitter (1999). O desenvolvimento radicular observado entre 12 e 21 dias provavelmente se relacionou à atividade de crescimento de novas raízes como será explicado no item 4.2. 


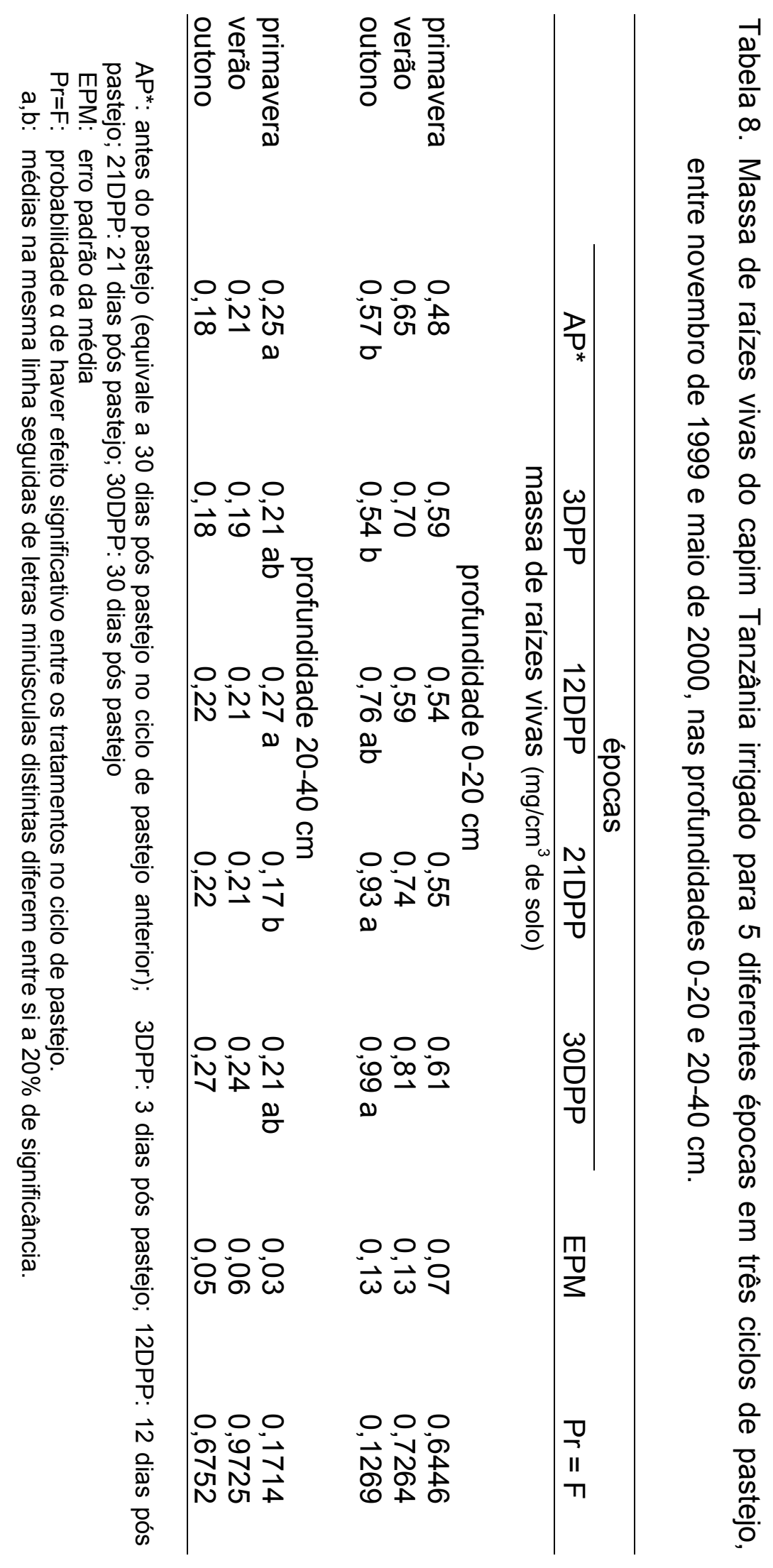




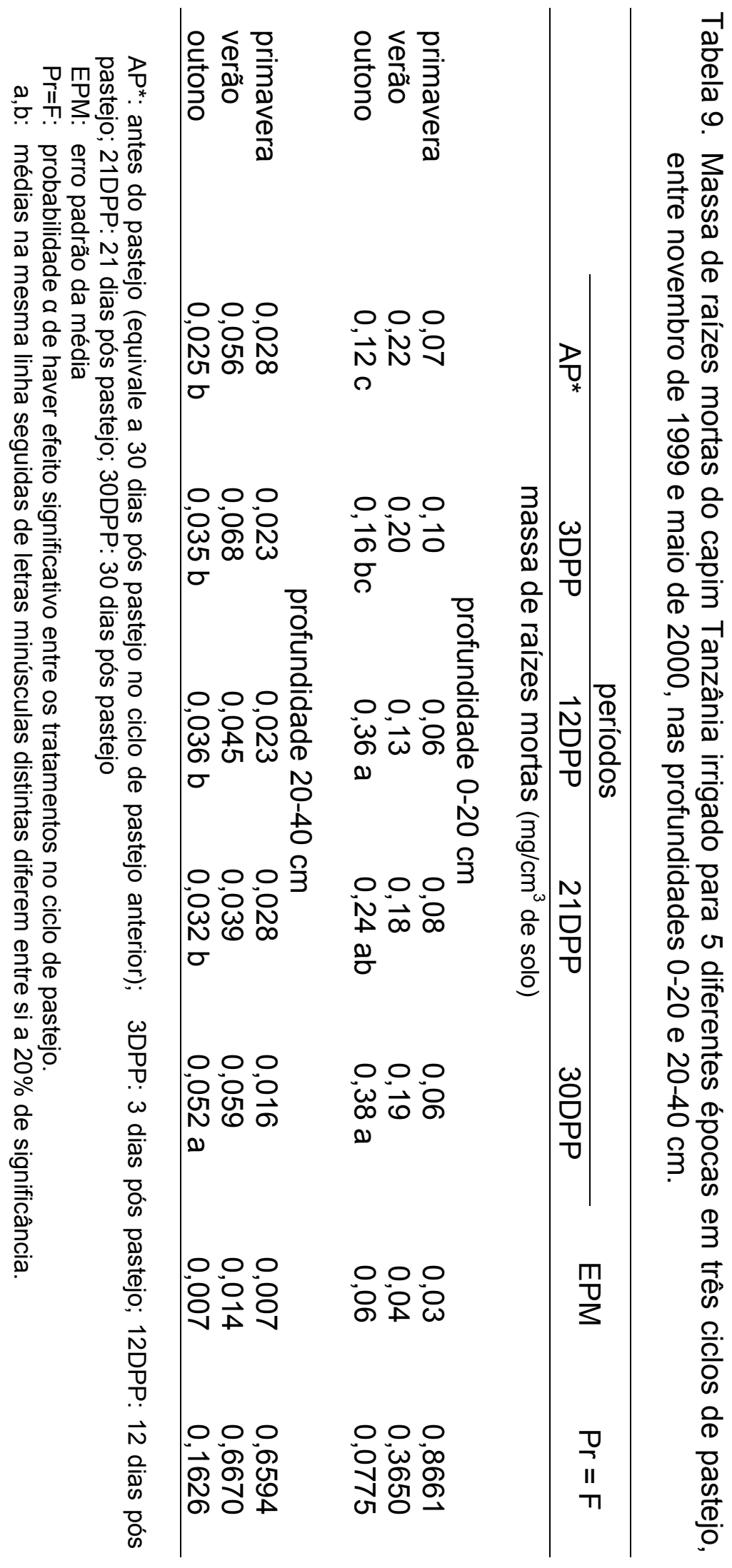




\subsection{EXPERIMENTO II - Dinâmica da retomada de crescimento do sistema radicular do capim Tanzânia após o pastejo.}

Através do desenvolvimento do sistema radicular do capim Tanzânia em covas preenchidas com areia, foi possível analisar a dinâmica da retomada do crescimento das raízes, conforme proposto por Mathew (1992).

A Tabela 10 mostra os resultados obtidos em dois ciclos de pastejo, que ocorreram entre o final da primavera do ano de 1999 e o final do verão de 2000.

A análise dos dados mostra diferença entre os tratamentos, de modo que T3 eT2 se mostraram semelhantes, sendo superiores ao T1. Esta informação explica a menor quantidade de raízes observada em várias situações para o T1 no experimento anterior (item 4.1.1), permitindo-nos observar um menor desenvolvimento radicular quando a planta foi pastejada mais intensamente.

Tabela 10. Desenvolvimento em areia do sistema radicular do capim Tanzânia irrigado para diferentes resíduos pós pastejo (T1 - $1000 \mathrm{~kg} \mathrm{MSV.ha}$

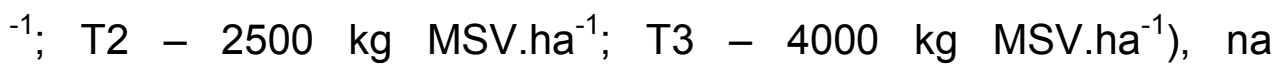
profundidade $0-20 \mathrm{~cm}$, em dois ciclos de pastejo.

\begin{tabular}{|c|c|c|c|c|c|}
\hline & \multicolumn{3}{|c|}{ tratamentos } & \multirow{2}{*}{ EPM } & \multirow{2}{*}{$\operatorname{Pr}=\mathrm{F}$} \\
\hline & $\mathrm{T} 1$ & T2 & T3 & & \\
\hline \multicolumn{6}{|c|}{ massa de raízes (mg/sonda*) } \\
\hline $\begin{array}{l}\text { primavera } \\
\text { verão }\end{array}$ & $\begin{array}{l}22,13 \mathrm{~B} \\
27,42 \mathrm{~B} \\
\end{array}$ & $\begin{array}{l}46,70 \mathrm{~A} \\
45,98 \mathrm{~A} \\
\end{array}$ & $\begin{array}{l}50,36 \mathrm{~A} \\
49,42 \mathrm{~A} \\
\end{array}$ & $\begin{array}{l}4,80 \\
4,17 \\
\end{array}$ & $\begin{array}{l}0,0051 \\
0,0021 \\
\end{array}$ \\
\hline
\end{tabular}

EPM: erro padrão da média

$\operatorname{Pr}=\mathrm{F}$ : probabilidade $\alpha$ de haver efeito significativo entre os tratamentos no ciclo de pastejo.

$A, B$ : médias na mesma linha seguidas de letras maiúsculas distintas diferem entre si a $7 \%$ de significância.

* volume ocupado pela sonda $=754 \mathrm{~cm}^{3}$ 
Considerando os resultados apresentados na Tabela 10 pode-se inferir que o capim Tanzânia irrigado pode ser manejado com resíduo pós

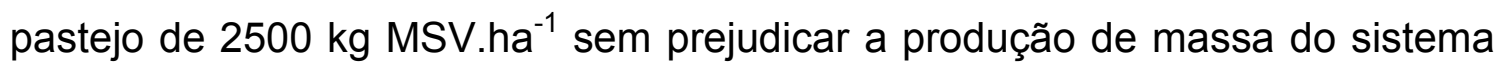
radicular. Entretanto, outras avaliações por período de tempo mais prolongado, são necessárias para se estabelecer a sustentabilidade e produtividade dessa gramínea sob irrigação e pastejo intensivo.

A dinâmica cronológica do desenvolvimento radicular para 3, 12, 21 e 30 dias após o pastejo é apresentada na Tabela 11.

Os resultados indicam que o desenvolvimento radicular do capim Tanzânia irrigado é retomado entre 12 e 21 dias após o pastejo. O efeito médio do pastejo impôs sobre a planta forrageira crescimento lento até 12 dias pós pastejo. Os resultados relativos ao acúmulo de massa de raízes demonstram que houve um estresse severo nos 3 primeiros dias após o pastejo, sendo este amenizado até 12 dias pós pastejo. Diferenças, entretanto, só foram observadas aos 21 dias pós pastejo considerando os resultados médios dos tratamentos estudados. Resultados semelhantes foram encontrados por Donaghy \& Fulkerson (1998), onde plantas de azevém cessavam o desenvolvimento radicular após a desfolha, no sentido de refazer nova área foliar. Estes autores verificaram diminuição da atividade radicular e aumento na mortalidade destas raízes quando a planta foi submetida a desfolhas mais severas e/ou freqüentes. 
Tabela 11. Desenvolvimento em areia do sistema radicular de capim Tanzânia irrigado para diferentes épocas em dois ciclos de pastejo, na profundidade $0-20 \mathrm{~cm}$.

\begin{tabular}{|c|c|c|c|c|c|c|}
\hline & \multicolumn{4}{|c|}{ épocas } & \multirow{2}{*}{ EPM } & \multirow{2}{*}{$\operatorname{Pr}=F$} \\
\hline & 3DPP & 12DPP & 21DPP & 30DPP & & \\
\hline \multicolumn{7}{|c|}{ massa de raízes $\left(\mathrm{mg} / \mathrm{sonda}^{\star}\right)$} \\
\hline primavera & $0,67 \mathrm{C}$ & $8,97 \mathrm{C}$ & $49,42 \mathrm{~B}$ & $99,87 \mathrm{~A}$ & 5,67 & 0,0001 \\
\hline verão & $7,58 \mathrm{C}$ & $11,21 \mathrm{C}$ & $48,06 \mathrm{~B}$ & $96,91 \mathrm{~A}$ & 4,82 & 0,0001 \\
\hline
\end{tabular}

3DPP: 3 dias pós pastejo; 12DPP: 12 dias pós pastejo; 21DPP: 21 dias pós pastejo; 30DPP: 30 dias pós pastejo

EPM: erro padrão da média

$\operatorname{Pr}=\mathrm{F}$ : probabilidade $\alpha$ de haver efeito significativo entre os tratamentos no ciclo de pastejo.

$A, B$ : médias na mesma linha seguidas de letras maiúsculas distintas diferem entre si a $7 \%$ de significância.

* volume ocupado pela sonda $=754 \mathrm{~cm}^{3}$

Um crescimento mais intenso foi observado entre 12 e 30 dias pós pastejo para o sistema radicular do capim Tanzânia irrigado, não se verificando tendência de estabilização no período analisado. Entretanto, a "não estabilização" no desenvolvimento do sistema radicular parece não estar associada à adaptação da planta dentro do ciclo de pastejo proposto, uma vez que as taxas de acúmulo de forragem foram altas, suportando elevadas lotações animais (Penati et al. 2001) com a planta forrageira mantendo-se vigorosa e com dossel livre de invasoras, confirmando o potencial de rebrota e sustentabilidade do sistema de produção.

Esse fato comprova a necessidade de estudos que procurem definir a interação entre o desenvolvimento do sistema radicular e a concentração de nutrientes do solo. Aparentemente, os resultados sugerem que, para o nível estudado de fertilidade do solo, condições de irrigação e sob o substrato uilizado, o acúmulo de massa de raízes do capim Tanzânia próximo à data do pastejo ao redor de $0,13 \mathrm{mg} \cdot \mathrm{cm}^{-3}$, ou $100 \mathrm{mg} \cdot$ sonda $^{-1}\left(1\right.$ sonda $\left.=754 \mathrm{~cm}^{3}\right)$, na 
profundidade $0-20 \mathrm{~cm}$, esteja próximo da suficiência para garantir elevada produtividade dessas pastagens.

As Figuras 7 e 8 ilustram esta hipótese, ressaltando através de uma abordagem estratificada que relaciona tratamento e época, o diferencial de crescimento radicular para os 3 tratamentos em todas as épocas amostradas.

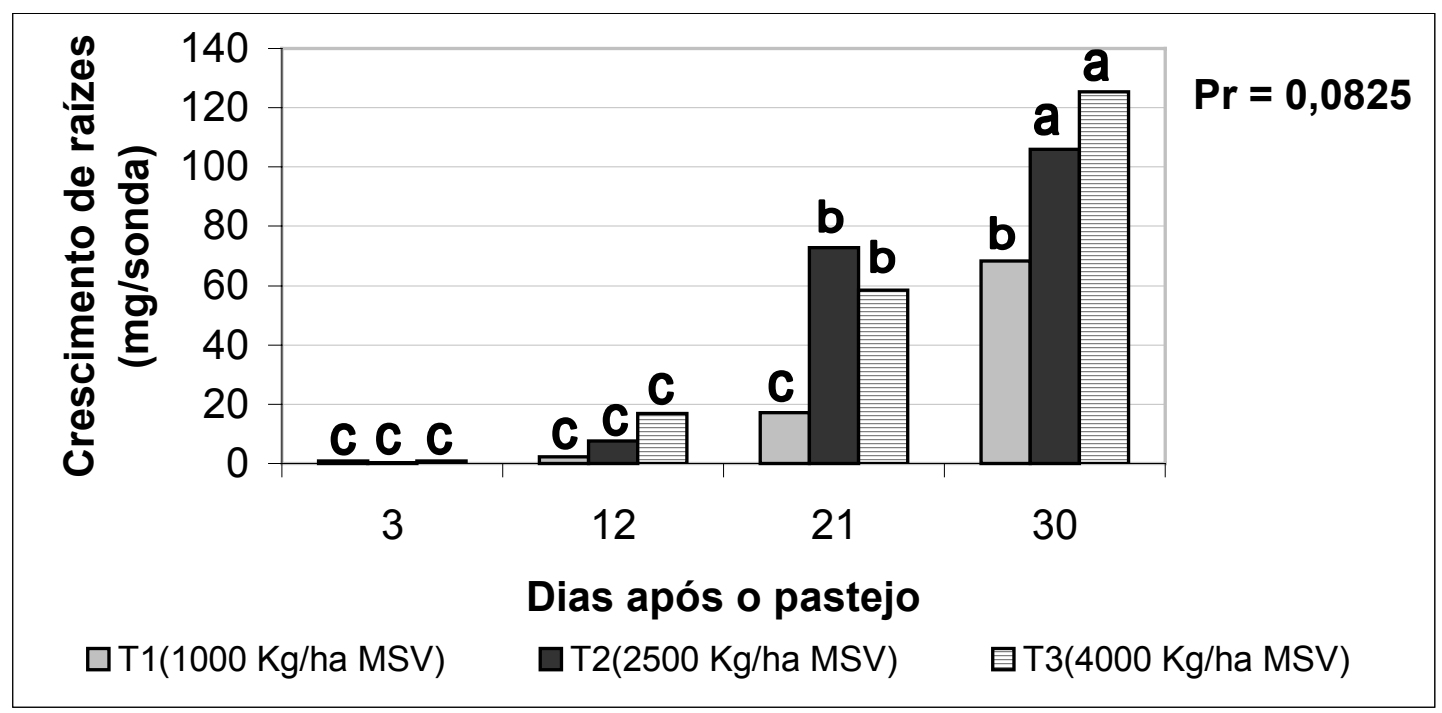

Figura 7 - Crescimento pós-desfolha do sistema radicular do capim Tanzânia irrigado submetido a três resíduos pós-pastejo no período de primavera, para a profundidade $0-20 \mathrm{~cm}$. 


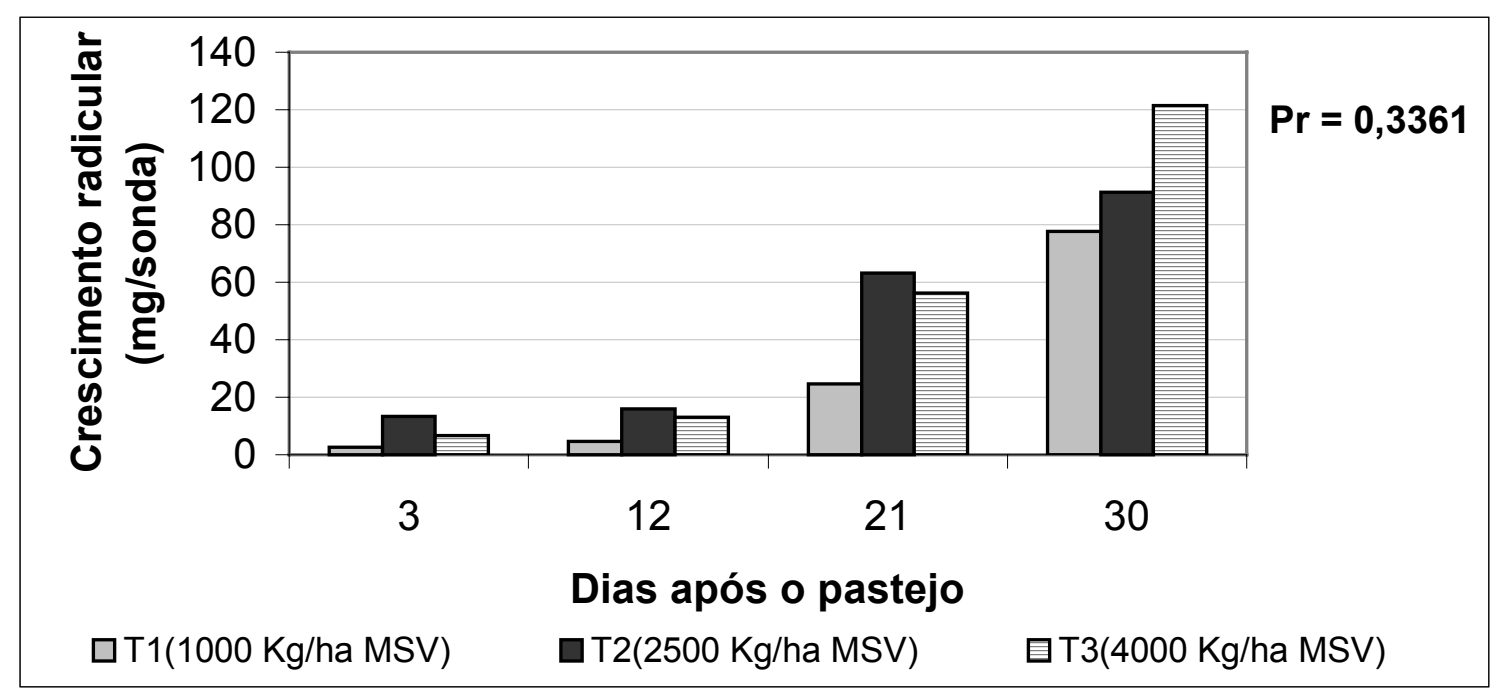

Figura 8 - Crescimento pós-desfolha do sistema radicular do capim Tanzânia irrigado submetido a três resíduos pós-pastejo no período de verão, para a profundidade $0-20 \mathrm{~cm}$.

Os resultados apresentados nas Figuras 7 e 8 indicam a paralisação no crescimento do sistema radicular até 21 dias após o pastejo quando a planta

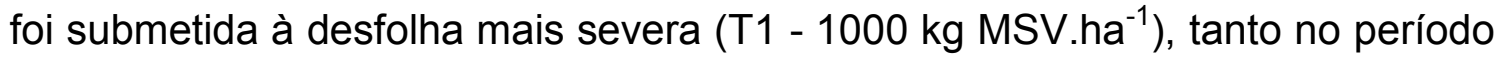
de primavera como no verão. Por outro lado, não foram encontradas diferenças na recuperação do sistema radicular para a desfolha intermediária (T2 - $2500 \mathrm{~kg}$

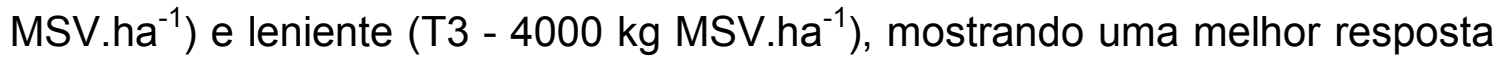
do sistema radicular nestes tratamentos quanto ao manejo proposto.

Estes resultados sugerem que o resíduo pós pastejo intermediário pode ser recomendado para o manejo desta forrageira sob pastejo rotacionado irrigado. Esta informação, entretanto, deve se associar a taxas de acúmulo de forragem e desempenho animal. Resultados preliminares de estudo desenvolvido por Penati et al. (2001) na mesma área experimental, indicam esta tendência, dando suporte às hipóteses apresentadas. 
A ausência no desenvolvimento radicular foi observada em todos os tratamentos para os primeiros 12 dias após o pastejo, semelhantemente ao que ocorre com forrageiras de clima temperado (Evans, 1976; Mathew, 1992; Donaghy \& Fulkerson, 1998). Isto aconteceu, provavelmente, devido à alteração no fluxo de reservas, de maneira a suprir o dreno metabólico proveniente do desenvolvimento de folhas jovens e, consequentemente, recuperação de área fotossintética. Este comportamento parece ratificar a idéia da existência de um balanço funcional entre raízes e parte aérea (Brower, 1983).

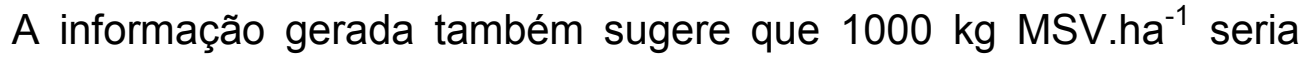
insuficiente para garantir a recuperação do capim Tanzânia com pastejos na frequência de 30 dias. A lenta recuperação do sistema radicular quando a planta forrageira é submetida ao pastejo intenso (T1) deve reduzir a longevidade desta planta forrageira, mesmo sob irrigação e em áreas bem adubadas, conforme foi observado neste trabalho. 


\section{CONCLUSÕES}

O desenvolvimento do sistema radicular da cultivar Tanzânia de Panicum maximum mostrou comportamento inversamente proporcional às intensidades de pastejo impostas, relacionando pastejos intensos a uma retomada mais lenta na atividade de raízes.

Sob condição de irrigação e bons níveis de adubações, o resíduo $1000 \mathrm{~kg} \mathrm{MSV}$.ha ${ }^{-1}$ mostrou menor atividade radicular em relação aos

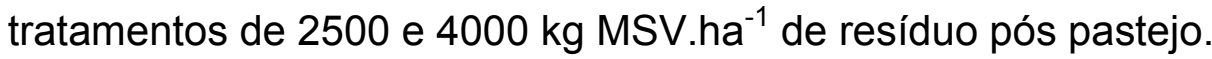

Para o perfil de solo analisado $(0-40 \mathrm{~cm})$, na média dos 3 tratamentos, $76 \%$ das raízes vivas e $82 \%$ das raízes mortas foram encontradas nos primeiros $20 \mathrm{~cm}$ de solo. Estes resultados indicam a possibilidade de novas pesquisas utilizarem apenas esta profundidade para amostragens, uma vez que os valores são relevantes e a dificuldade de coleta em maiores profundidades é fator limitante para estes estudos.

Até 12 dias após o pastejo não houve crescimento de novas raízes, indicando que a planta fica sob condição de estresse até pelo menos 2 semanas após ser colhida, independente do manejo imposto. No entanto, para o pastejo mais intenso (resíduo $1000 \mathrm{~kg} \mathrm{MSV} . \mathrm{ha}^{-1}$ ), o desenvolvimento radicular ficou comprometido até 3 semanas após o pastejo. 
A separação de raízes vivas pareceu ser uma boa metodologia para melhorar a acuracidade na análise dos resultados, já que amostragens do sistema radicular de plantas forrageiras apresentam alta variabilidade.

Estudos que relacionem a decomposição e renovação do sistema radicular de forrageiras tropicais com fatores bióticos e abióticos deveriam ser intensificados, buscando melhor entendimento dos fluxos de tecidos da planta inteira em diferentes estações do ano.

Metodologias de amostragens associadas a conceitos de interpretação estatística em processos biológicos deveriam ser revistos, uma vez que os estudos existentes sobre sistema radicular de plantas forrageiras tropicais poucas vezes são conclusivos quando interpretados pela estatística ortodoxa. 


\section{REFERÊNCIAS BIBLIOGRÁFICAS}

ADJEI, M. B.; MISLEVY, P.; WEST, R. L. Effect of stocking rate on the location of storage carbohydrates in the stubble of tropical grasses. Tropical Grasslands, v.22, n.2, p. 50-56, 1988.

AMARAL, E. F. Quantificação de raízes utilizando imagens digitais. Boletim informativo $n^{\circ}$ 125. Rio Branco: EMBRAPA, p.1-3, agosto 1998.

BONO, J. A. M.; MACEDO, M. C. M.; EUCLIDES, V. B. P. Biomassa e área do sistema radicular e resistência do solo à penetração em pastagens de Panicum maximum Jacq. sob pastejo rotacionado (compact disc). In: REUNIÃO DA SOCIEDADE BRASILEIRA DE ZOOTECNIA, 37., Viçosa, 2000. Anais. Viçosa: UFV, 2000.

BOTREL, M. A. Importância dos carboidratos de reserva e da preservação dos meristemas apicais na rebrota do capim jaraguá (Hyparrhenia rufa (Ness) Stapf.). Viçosa, 1980. 41p. Dissertação (M.S.) - Universidade Federal de Viçosa.

BROUGHAM, R. W. Effect of intensity of defoliation on regrowth of pasture. Australian Journal of Agricultural Research, v.7, n.2, p.377-387, 1956.

BROUWER, R. Functional equilibrium between shoots and roots. Netherlands Journal of Agricultural Science. v.31, p.335-348, 1983. 
CARVALHO, M.C.S. Práticas de recuperação de uma pastagem degradada e seus impactos em atributos físicos, químicos e microbiológicos do solo. Piracicaba, 1999. 103p. Tese (Doutorado) - Escola Superior de Agricultura "Luiz de Queiroz", Universidade de São Paulo.

CHACÓN-MORENO, E.; RADA, F.; SAMIENTO, G. Intercambio gaseoso, nitrógeno foliar y optimación en el manejo de Panicum maximum (tipo común) sometido a diferentes frecuencias de corte. Turrialba, v.45, p.19-26, 1995.

CORSI, M. Effects of nitrogen rates and harvesting intervals on dry matter productivity, tillering and quality of the tropical grass Panicum maximum, Jacq., Ames, 1984. 125p. Thesis (Ph.D.) - Ohio State University.

CORSI, M. Pastagens de alta produtividade. In: PEIXOTO, A. M.; MOURA, J. C.; FARIA, V. P. (Ed.) Pastagens: fundamentos da exploração racional. Piracicaba: FEALQ, 1994. p.477-494.

CORSI, M.; MARTHA JÚNIOR, G. B.; PAGOTTO, D. S. Sistema radicular: dinâmica e resposta a regimes de desfolha. In: MATTOS, W.R.S.; FARIA, V.P.; SILVA, S.C.; NUSSIO, L.G.; MOURA, J.C. (Ed.) A produção animal na visão dos brasileiros. Piracicaba: FEALQ, 2001. p. 838-852.

CORSI, M.; NASCIMENTO Jr., D. Princípios de fisiologia e morfologia de plantas forrageiras aplicados no manejo das pastagens. In: PEIXOTO, A. M.; MOURA, J. C.; FARIA, V. P. (Ed.). Pastagens: fundamentos da exploração racional. Piracicaba: FEALQ, 1994. p. 15-48.

DAVIDSON, L. R. Root system - the forgotten component of pastures. In: WILSON, J. R. (Ed.) Plant relations in pastures. Brisbane: CSIRO, 1978. p.86-94. 
DONAGHY, D.J., FULKERSON, W.J. Priority for allocation of water soluble cabohydrate reserves during regrowth of Lollium perenne. Grass and Forage Science, v.53, p.211-218, 1998.

DOVRAT, A., DAYAN, E., VAN KEULEN, H. Regrowth potential of shoot and of roots of Rodes grass (Chloris gayana) after defoliation. Netherland Journal of Agricultural Science, v.28, p.185-199, 1980.

EVANS, P.S. The effect of repeated defoliation to three different levels on root growth of five pasture species. New Zealand Journal of Experimental Agriculture, v.16, p.31-34,1976.

FISCUS, E.L. ; MARKHART, A.H. Relationship between root system transport properties and plant size in Phaseolus vulgaris. Plant Physiology, v.64, p.770-773, 1979.

FITTER, A. H. Roots as dynamics systems: the developmental ecology of roots and root systems. In: SCHOLES, J. D.; BARKER, M.G. (Ed.) Physiological plant ecology. M.C. Press, 1999. p.115-130.

GOMIDE, J. A. O fator tempo e o número de piquetes do pastejo rotacionado. In: SIMPÓSIO SOBRE MANEJO DA PASTAGEM, 14., Piracicaba, 1997. Anais. Piracicaba: FEALQ, 1997. p.253-272.

GOMIDE, J. A.; OBEID, J. A.; RODRIGUES, L. R. A. Fatores morfofisiológicos de rebrota do capim colonião (Panicum maximum Jacq.). Revista da Sociedade Brasileira de Zootecnia, v.8, n.4, p.532-560, 1979.

GREGORY, P.J. Root growth and activity. In: Physiology and determination of crop yield. Madison: ASA/CSSA/SSSA, 1994. p.65-93. 
GROSS, C. D. Efeitos do desfolhamento sobre os níveis das frações nitrogenadas, carboidratos e fenóis solúveis em raízes de braquiária (Brachiaria decumbens, Stapf.). Piracicaba, 1988. 97p. Dissertação (Mestrado) - Escola Superior de Agricultura "Luiz de Queiroz", Universidade de São Paulo.

HARRIS, W. Defoliation as a determinant of the growth, persistence and composition of pastures. In: WILSON, J. R. (Ed.) Plant relations in pastures. Brisbane: CSIRO, 1978. p.67-85.

HOPKINS, W.G. Introduction to plant physiology. New York: John Wiley, 1995. 464p.

HUMPHREYS, L. R. Pasture defoliation practice: a review. Journal of Australian Institute of Agricultural Science, v.32, p.93-105, 1966.

HUMPHREYS, L. R. Tropical pastures utilisation. Cambridge: Cambridge University Press, 1991. 206p.

HUMPHREYS, L.R.; ROBINSON, A. R. Interrelations of leaf area and non structural carbohydrate status as determinants of the growth subtropical grasses. In: INTERNATIONAL GRASSLAND CONGRESS, 10., Proceedings. Helsinki, 1966. p.113-116.

JEWISS, O. R. Tillering in grasses - its significance and control. Journal of the British Grasslands Society, v.27, p.65-82, 1972.

JONES, C. A.; CARABALY, A. Some characteristics of regrowth of 12 tropical grasses. Tropical Agriculture, v.58, n.1, p.37-44, 1981. 
KRAMER, P.J. Water relations of plants. Orlando: Academic Press, 1983. $489 p$.

KRAMER, P. J.; KOZLOWSKI, T. T. Physiology of woody plants. London: Academic Press. 1979.

LEMAIRE, G. The physiology of grass growth under grazing: tissue turnover. In: SIMPÓSIO INTERNACIONAL SOBRE PRODUÇÃO ANIMAL EM PASTEJO, Viçosa, 1997. Viçosa: UFV, 1997. p.117-144.

LEMAIRE, G.; CHAPMAN, D. Tissue flows in grazed plant communities. In: HODGSON, J.; ILLIUS, A.W. (Ed.) The ecology and management of grazing systems. Wallingford: CAB International, 1996. p.3-36.

LOUAHLIA, S., LAINÉ, P., OURRY, A., BOUCAUD, J. The role of $\mathrm{N}$ remobilization and the uptake of $\mathrm{NH}_{4}{ }^{+}$and $\mathrm{NO}_{3}{ }^{-}$by Lollium perenne $\mathrm{L}$. in laminae growth following defoliation under field conditions. Plant and Soil, v.220, p.175-187, 2000.

MARTHA JÚNIOR, G.B. Balanço de ${ }^{15} \mathrm{~N}$ e perdas de amônia por volatilização em pastagem de capim-elefante. Piracicaba, 1999. 75p. Dissertação (Mestrado) - Escola Superior de Agricultura "Luiz de Queiroz", Universidade de São Paulo.

MATTHEW , C; KEMBALL, W.D. Alocation of carbon-14 to roots of different ages in perennial ryegrass (Lolium perene, L.) In: INTERNATIONAL GRASSLAND CONGRESS, 17., Winnipeg/Saskaton, 1997. Proceedings. Winnipeg/Saskaton: CFC/CSA/CSAS, 1997 (compact disk). 
MATTHEW, C. A study of seasonal root and tiller dynamics in swards of perennial ryegrass (Lolium perenne, L.). Palmerston North, 1992. 247p. Thesis (Ph.D.) - Massey University.

MELLO, A.C.L.; SANTOS, P.M.; PEDREIRA, C.G.S.; CORSI, M.; DIAS, C.T.S. Photosyntetic light response of Tanzânia grass under four levels of leaf temperatures. In: INTERNATIONAL GRASSLAND CONGRESS, 19., Piracicaba, 2001. Proceedings. Piracicaba: FEALQ, 2001. p.73-74.

MENGEL, K; KIRKBY, E. A. Principles of plant nutrition. Bern: International Potash Institute, 1982. 593p.

MILLARD, P., THOMAS, R.J., BUCKLAND, S.T. Nitrogen supply affects the remobilization of nitrogen or the regrowth of defoliated Lollium perenne $\mathrm{L}$. Journal of Experimental Botany, v. 41, p.941-947, 1990.

MILTHORPE, F. L.; DAVIDSON, J. L. Physiological aspects of the growth in grasses. In: MILTHORPE, F.L.; IVINS, J. (Ed.) The growth of cereal and grasses. 1966. p.241-254.

NABINGER, C. Eficiência do uso de pastagens: disponibilidade e perdas de forragem. In: SIMPÓSIO SOBRE MANEJO DA PASTAGEM, 14., Piracicaba, 1997. Anais. Piracicaba: FEALQ, 1997. p.213-252.

NASCIMENTO, M. P. S. C. B.; NASCIMENTO, H. T. S.; GOMIDE, J. A. Alguns aspectos morfológicos de três gramíneas de clima tropical. Revista da Sociedade Brasileira de Zootecnia, v.9, n.1, p.142-158, 1980. 
PENATI, M.A.; MAYA, F.L.A.; CORSI,M.; BALSALOBRE, M.A.A.; SANTOS, P.M.; PAGOTTO, D.S.; BARIONI, L.G.; MARTHA JÚNIOR, G.B. Resposta da taxa de lotação animal em pastagem irrigada de capim tanzânia manejada em três níveis de massa de forragem pós pastejo. In: REUNIÃO DA SOCIEDADE BRASILEIRA DE ZOOTECNIA, 38., Piracicaba, 2001. Anais. Piracicaba: FEALQ, 2001. p.346-348.

RICHARDS, J. H. Root growth response to defoliation in two Agropyron bunchgrasses: field observations with an improved root periscope. Oecologia, v.64, p.21-25, 1984.

RODRIGUES, A.C.G.; CADIMA-ZEVALLOS, A. Efeito da intensidade de pastejo sobre o sistema radicular de pastagem. Pesquisa Agropecuária Brasileira, v.26, n.3, p. 439-445, mar. 1991.

RODRIGUES, L. R.; RODRIGUES, T. J. D.; RAMOS, A. K. B.; QUADROS, D.G. Dry matter production of shoots and root density of two cultivars of Lablab purpureus (L.) Sweet. In: INTERNATIONAL GRASSLAND CONGRESS, 19., Piracicaba, 2001. Proceedings. Piracicaba: FEALQ, 2001. p.573-574.

RODRIGUES, L. R.; RODRIGUES, T.J. D. Ecofisiologia de plantas forrageiras. Ecofisiologia da produção agrícola. Piracicaba: POTAFÓS, 1987. p.201230.

SANDERSON, M. A.; STAIR, D. W.; HUSSEY, M. A. Physiological and morphological responses of perennial forages to stress. Advances in Agronomy, v.59, p.171-224, 1997.

SAS INSTITUTE. SAS/STAT: user's guide, version 6. Cary, 1991. 2v. 
SCURLOCK, J. M. O.; HALL, D. O. The global carbon sink: a grassland perspective. Global Change Biology, v.4, p.229-233, 1998.

SENTELHAS, P. Base de dados do posto agrometeorológico, área de física e meteorologia DCE - ESALQ - USP. Piracicaba: julho, 2001. http://ce.esalq.usp.br/dce/postocon.htm

SHEEHY, J. E.; JOHNSON, I. R. Physiological models of grass growth. In: JONES, M. B.; LAZENBY, A. (Ed.) The grass crop: the physiological basis of production. London: Chapman and Hall, 1988. p.243-275.

SILVA, S. C.; PEDREIRA, C. G. S. Princípios de ecologia aplicados ao manejo da pastagem. In: SIMPÓSIO SOBRE ECOSSISTEMAS DE PASTAGENS, 3., Jaboticabal, 1997. Anais. Jaboticabal: UNESP, FCAV, 1997. p.1-62.

SMITH, D. The nonstructural carbohidrates. In: BUTLER, G. W.; BAYLEI, R. W. (Ed.) Chemistry and biochemistry of herbage. London: Academic Press, 1973. p.105-155.

SOARES FILHO, C. V. Variação sazonal de parâmetros bioquímico fisiológicos em Brachiaria decumbens estabelecida em pastagens. Piracicaba, 1991. 110p. Dissertação (Mestrado) - Escola Superior de Agricultura "Luiz de Queiroz", Universidade de São Paulo.

TAIZ, L.; ZEIGER, E. Plant physiology. Redwood City: The Benjamin Cummings Publ., 1991. 559p.

TAYLOR, H. M. Managing roots systems to reduce plant water deficits. In: MEHTA, Y. R. (Ed.) The soil root systems in relation to Brazilian agriculture. Londrina: IAPAR, 1981. p.45-60. 
TENNANT, D. A test of a modified line intersect method of estimating root length. Journal of Ecology, v.63, p.995-1001. 1975.

THORNTON, B.; MILLARD, P. The effects of nitrogen supplyand defoliation on the seasonal internal cycling of nitrogen in Molinia caerulea. Journal of Experimental Botany, v.44, p.531-536. 1993.

TOSI, P. Estabelecimento de parâmetros fisiológicos para o manejo e eficiência de utilização de Panicum maximum Jacq. cv. Tanzânia, sob pastejo rotacionado. Piracicaba, 1999. 105p. Dissertação (Mestrado) - Escola Superior de Agricultura “Luiz de Queiroz”, Universidade de São Paulo.

VOGT, K. A.; BLOOMFIELD, J. Tree root turnover and senescense. In: WAISEL, Y.; ESHEL, A.; KAFKAFI, U. Plant roots: the hidden half. New York: Marcel Dekker, Inc, 1991. p.287-308.

VOGT, K. A.; PERSSON, H. Root methods. In: LASSOIE, J. P.; HINCKLEY, T. M. Ecophysiology of forest trees. Boca Raton: CRC Press, 1991.

YOUNGNER, V. B. Physiology of defoliation and regrowth. In: YOUNGNER, V. B.; McKELL, C. M. (Ed.) The biology and utilization of grasses. New York: Academic Press, 1972. p.292-303. 